\title{
THE POLITICS OF BASING POINT LEGISLATION
}

\author{
EARL Latham*
}

The Cement case of 1948 was decided in April of that year. ${ }^{1}$ It outlawed a more or less obvious form of price fixing by conspiracy to use a basing point system in forbidden ways. The case aroused an immediate controversy and a din of conflicting counsels was raised. Few cared or dared to attack the principal holding directly. Many said they saw in dicta a covert menace to free and independent enterprise. It was asserted that the law now required all sellers to quote prices f.o.b. mill, and that it inhibited every enterpriser from ever meeting the lower price of a competitor. By December, 1948, a former chairman of the Federal Trade Commission was moved to say of this view, that he had to agree with Mr. Bumble: "If the law supposes that, the law is a ass, a idiot."'

This essay concerns itself with the drive to have Congress take legislative action to "clarify" the law which was assumedly made unclear by the Cement case of 1948. The movement began with the creation of the Capehart Committee in the closing months of the Second Session of the Eightieth Congress, and ended in stalemate (perhaps only temporary) in the closing days of the First Session of the Eightyfirst Congress. The sequence of events provides an excellent case study of the way in which public policy was formulated in a controversial and technical field where strong and weighty interests have vested.

\section{Overture to the Capehart Committee}

Representatives from the great steel state of Pennsylvania acted quickly after the Cement case of r948. Both Representative Francis E. Walter and Senator Francis S. Myers introduced bills in the House and Senate respectively to provide a moratorium on further proceedings under the decision and to authorize an investigation of its effects. ${ }^{3}$ Senator Capehart of Indiana, however, had also introduced a resolution to investigate the impact of the Cement decision on consumers and business.

\footnotetext{
- Joseph B. Eastman Professor of Political Science, Amherst College, Amherst, Mass.

1 Federal Trade Comm'n v. Cement Institute, 333 U. S. 683 (1948).

a Robert Elliott Freer, Let's Stop Kicking the Anti-Trust Laws Around, remarks prepared for delivery before the Sales Executives Club of New York, Roosevelt Hotel, New York City, Decembcr 7, 1948. N. Y. Times, Dec. 8, I948, p. 49, col. 2. Some currency had been given to this view by another member of the Federal Trade Commission, Lowell Mason. See remarks of Lowell B. Mason before the Boston Conference on Distribution, Boston, Mass., Oct, 26, 1948. A statement released to the press in the name of the Federal Trade Commission, however, denied that the law forbade freight absorption or prevented meeting competitor's prices. See FTC, Notice to the Staff, In Re: Commission Policy Toward Geographic Pricing Practices (October 12, 1948).

${ }^{3}$ H. R. 2222 and S. roo8, 8ist Cong., Ist Sess. (I949); 95 Cong. Rec. 9168 (July 6, r949).

'S. Res. 24I, 8oth Cong., rst Sess. (1948), introduced by Senator Capehart and referred to the Senate Committee on Interstate and Foreign Commerce, 94 Cong. Rec. 6158 (May 18, I948); reported
} 
Since the Walter, Myers, and Capehart resolutions all provided substantially for the same thing, a conference was arranged between Walter, the majority floor leader (Halleck of Indiana), and the chairman of the House Committee on the Judiciary to clear the brief tangle. Representative Walter in the House agreed not to press his resolution in that body and withdrew in favor of the Senate hearing which had been authorized by the Capehart resolution. If the House and the Senate had run hearings on the same subject at the same time, there would undoubtedly have been a duplication of witnesses and testimony. ${ }^{5}$

The reaction of the steel industry to the Cement case was at first mixed, with opinion divided as to next steps for steel. ${ }^{6}$ The Cement case had outlawed conspiratorial use of a multiple basing point system of delivered prices among cement companies. The chairman of United States Steel said that its subsidiary, Universal Atlas Cement Company, would comply with the Court's order. The big question was whether the Court's decision affected the use of basing point formulas in pricing steel. Some wanted to await the outcome of the Federal Trade Commission's case against the manufacturers of rigid steel conduit, and others wanted to press for Congressional legislation immediately, to protect the steel industry's pricing system, even though the question of its legality was then in the processes of litigation. By June, r948, there were strong rumors that the steel industry would press for legislation to protect the basing point system in steel. It was the opinion of Senator Morse that the steel industry intended not merely to have the existing law "clarified" but to validate the basing point system in steel, whatever the meaning of the existing law. ${ }^{7}$

The point is of some importance because Senator Capehart repeatedly asserted that the existing law was so confused that clarification was necessary, and that businessmen should be informed by Congress that it was legal and proper for them to absorb freight in quoting prices to buyers. This was also the official theory of the O'Mahoney Bill which was introduced in the First Session of the Eighty-first Congress, and which will be discussed more fully below. ${ }^{8}$ It is difficult, if not impossible, to ascertain with exactness the intention of the steel industry in this matter, but there is certainly a sense in which it could be argued that the trouble with the existing law was not that it was unclear, but that it was becoming painfully clear, and that the hope of practitioners of the basing point system was not to clarify the trend, but to reverse it. $^{9}$ Some supporters of the O'Mahoney Bill at least thought they were making basing point systems safe. ${ }^{10}$

\footnotetext{
with amendments (SEN. REP. No. 1566) and referred to the Committee on Rules and Administration, 94 Cong. Rec. 750x (June 4, r948); reported back, 94 Cong. Rec. 7949 (June ro, 1948); passed Senate as amended, 94 Cong. Rec. 7949 (June 10, r948).

95 Cong. Rec. 7949 (June 10, 1948).

- For a description of these events, see speech of Senator Wayne Morse of Oregon, 95 Cong. Rec. $7162-7169$ (May 31, 1949).

75 Cong. Rec. 7163 (May 3r, 1949).

${ }^{8}$ See pages 292 ff. infra.

- For a good statement of the meaning of the law, see Note, 58 YALE L. J. 426 (I949).

${ }^{10} \mathrm{Sec}$ remarks of Representative Crawford of Michigan on the floor of the House: ". . . if the
} 
On July 7, I948, United States Steel abandoned the basing point system of delivered prices and changed to f.o.b. mill. ${ }^{11}$ Although the steel industry was not required by the Cement case to go f.o.b., ${ }^{12}$ and although the steel industry was shown by one witness to have gone on an f.o.b. basis before the Cement case in some instances, $^{13}$ the impression became fairly widespread that the Supreme Court had forced the steel producers to require their customers to pay the freight. ${ }^{14}$ It is interesting that although the steel industry (which was not involved) seemed to feel it necessary to go f.o.b., one of the respondents in the Cement case, according to its attorney, continued to sell cement priced and delivered at destination. ${ }^{15}$ The new policy of United States Steel raised the price of steel several dollars a ton. ${ }^{18}$ According to one of the witnesses before the House Small Business Committee in the summer of 1949, the change to f.o.b. pricing actually made the cost to the steel companies go down $\$$ r.oo a ton. ${ }^{17}$ A professor of political economy at Johns Hopkins University termed the steel company action an "attempt to deceive the consumers

basing point system is done away with, in accordance with the decisions of the Supreme Court, then I think we will have worse conditions from the standpoint of the expansion of monopolies and the destruction of small enterprise. . . "95 Cong. Rec. 9164-9r65 (July 6, 1949). And further, "I see nothing whatsoever in the basing point system which destroys competition." Ibid. Sec also remarks of Representative Walter of Pennsylvania, in which he said that the opponents of the O'Mahoncy bill are those who oppose basing point systems. Id. at 9r68. At another place Representative Walter said that the bill did not "reestablish" the basing point system but failed to answer directly whether it prohibited basing point systems from being reestablished. Id. at 9169 . The Department of Justice representative, testifying before the House Judiciary Committee, referred to the bill as basing point legislation without rebuke. Hearings before Subcommittee No. I of the House Committee on the Judiciary on S. 1008, 8Ist Cong., Ist Sess. ${ }_{3}$ (1949) (hereinafter cited as H. R. Hearings on S. 1008).

11 The Wall Street Journal quoted an unidentified manufacturer as saying, "The pressure on Congress to pass legislation making freight absorption a legal business practice probably will be terrific as a result of United States Steel's action. For a lot of steel users, it means higher prices; many toes will be punched. Apparently steel officials felt they couldn't win their price case before the courts, so they're using this means to take it to the people." Wall Street Journal, July 8, 1949, p. I, col. 6. Fortune said two months later, ". . . as a general rule business has far more to gain through placing its faith in the slow interpretation of law by the courts than in political action. The latter is apt to yield more confusion and bitterness. The former, however difficult, can give the kind of continuity that makes industrial democracy possible." Fortune, September 1948, p. 79.

${ }^{12}$ See Corwin Edwards, New England Council Speech, September 18, I948: "The Commission has no authority to require businessmen to sell f.o.b. mill or to impose upon them any other spccific pricing practice."

${ }^{12}$ Testimony of Otis Brubaker, United Steelworkers of America, CrO, in Hearings before a Subcommittee of the Senate Committee on the Judiciary on S. 1008, 81st Cong., 1st Sess. 20 (1949) (hereinafter cited as Senate Hearings on $S$. 1008). The Senate Small Business Committee report, "Changes in Dis. tribution of Steel," accepted by Wherry and Martin, shows the same thing. Hearings, supra, at 20. See reaction of Senator Myers in Hearings before a Subcommittee of the Senate Committee on Interstate and Foreign Commerce on S. 236, 81st Cong., Ist Sess. 221 (1949) (hcreinafter cited as Senate Hearings on $S .236$ ).

is See the census of views taken by the National Small Business Men's Association, in Hearings before a Subcommittee of the Senate Committee on Interstate and Foreign Commerce on S. Res. 24t, 8oth Cong., 2d Sess. 30-49 (r948) (hereinafter cited as Senate Hearings on S. Res. 241), where some of those answering thought that the Supreme Court had specifically forced the steel industry into its action.

${ }^{15}$ Testimony of Edward A. Zimmerman, in Senate Hearings on S. 236 , at 247.

${ }^{16}$ Testimony of Otis Brubaker, Senate Hearings on S. 236 , at I95. Mr. Coyle estimated the increase at $\$ 9$ a ton. See note 17 , infra.

${ }_{17}$ Statement of David Cushman Coyle, in Hearings before the House Select Committee on Small Business, 81st Cong., Ist Sess. 97 (1949) (hereinafter cited as Small Business Committee Hearings). 
by telling them that freight absorption was unlawful and that delivered prices were, therefore, necessarily higher than before."18

Whatever may have been the motivation behind the decision to adopt f.o.b. pricing, the effect upon the customers of steel producing companies was rapid, loud, and insistent. A clamor was raised for legislative action, which the steel companies encouraged by direct solicitation. ${ }^{19}$ There was also evidence that dissident customers were reluctant to identify themselves because they might be disciplined by their suppliers. ${ }^{20}$ The Washington correspondent of the Rocky Mountain News discovered a public relations firm that had been hired at a compensation of at least $\$ \mathrm{Ir}, 000$ a month and expenses to get the law amended. According to his account, a National Competitive Committee was established with local chapters, and agents were sent about the country to organize others. The firm is said to have stood ready to perform such jobs "as delivering to a client a ready-made nation-wide grass-roots organization." Of this attempt to manufacture pressure, Senator Morse said: ${ }^{21}$

This lobbying effort was one of the best organized, one of the most heavily financed, and one of the most adroitly deceptive that has ever been addressed to the Congress of the United States.

\section{II}

\section{The Capehart Hearings}

With beaters in the states flushing the thickets, witnesses winged their way to Washington where they gave testimony to the Capehart Committee. ${ }^{22}$ The Committee officially consisted of Hawkes of New Jersey and Brewster of Maine on the Republican side, and Johnson of Colorado and McMahon of Connecticut on the Democratic side, with Capehart of Indiana as chairman. The major work of the Committee was done by the chairman and the general counsel, while the other members participated, presumably, as their busy schedules permitted. The stated purpose of the Senate resolution under which the Committee functioned was to inquire into existing legislation concerning government policy affecting the activities of the Federal Trade Commission and the Interstate Commerce Commission, and the impact of these policies as interpreted by the Supreme Court "with particular re-

\footnotetext{
${ }^{18}$ Statement of Professor Fritz Machlup, id. at $2 \times 4$.

${ }^{10}$ Specch of Senator Wayne Morse, 95 Cong. Rec. 7I63 (May 3I, I949). The forms of solicitation included suggestions by salesmen to customers that Congress be asked to legalize basing point practices, statements by company officials to the press, and letters by company officials to customers urging pressure upon Congressmen. See 95 Cong. Rec. 11575 (Aug. I2, 1949) for further details about the public relations program. See also letter from Ben Moreell, President, Jones \& Laughlin Steel Corporation, July 2r, 1948, to shareholders and employees, announcing new pricing policy and need for action by Congress. 95 Cong. Rec. xI585 (Aug. x2, I949). Ernest T. Weir, Chairman of the National Steel Corporation, followed a similar course. 95 Cong. Rec. 11585 (Aug. I2, 1949).

${ }_{20} 95$ Cong. Rec. 7164 (May 3I, 1949). A garden toolmaker was said to have made a price reduction of one per cent but feared reporting it because of the possibility of the loss of steel allocations. Even larger reductions were named by other manufacturers but fear of trade reprisals prevented them from declaring themselves. N. Y. Times, Oct. 14, I948, p. 45, col. 2.

${ }^{21} 95$ Cong. Rec. 7165 (May 31, I949).

23 The title of the Capehart Committee was Subcommittee of the Senate Committee on Interstate and Foreign Commerce on S. Res. $24 \mathrm{r}$.
} 
lation to the basing point or freight equalization system of pricing."23 The Committee was also to study the effect of the continuance or discontinuance of these pricing policies on the consumer and small businessman. In addition, it was charged with the duty of exploring the character and extent of industrial concentration in the United States. ${ }^{24}$ The resolution establishing the Committee was adopted on June I2, 1948, and on July 30 the Committee resolved to concentrate its first efforts upon the impact upon the economy of the new basing point law as interpreted and administered by the Federal Trade Commission and the courts. It never did get into the character and extent of industrial concentration in the United States.

In August, I948, the Committee appointed an advisory council to aid it in the inquiry directed by Senate Resolution 24r. Under the direction of a chairman, forty-five people were invited and participated in the deliberations of the council. The council met three times and made a final report to the Committee recommending modifications in the law for the relief of the business community. A representative of the National Farmers Union, who was a member of the council and who attended all of its meetings, found it objectionable because of its composition. ${ }^{25}$ Of the original members of the council, he said, there were three executives of the cement industry, whose case had started the entire controversy; a representative of one of the respondents in the Glucose cases of x945; and three representatives of steel companies who were respondents in a Federal Trade Commission case. There were also seven representatives of customers of the cement and steel industries. Transportation was represented by a representative of the railroads, which benefit under basing point schemes. There were no representatives of the trucking industry which does not benefit under basing point schemes. No representative was known as a strong anti-monopolist, nor were there representatives from government departments or agencies concerned with the enforcement of the antitrust laws. Of the labor representatives, one was the head of the Cement Workers Union, and one (United Steelworkers) withdrew. Of the farm groups, only two were originally represented-the American Farm Bureau Federation and the National Grange. The National Farmers Union was added at the instigation of Senator Johnson of Colorado. ${ }^{26}$ Congressman Patman of Texas repeated the observation of the National Farm Union representative that, ${ }^{27}$

The inclusion of representatives of three great farm organizations can be accounted for only on the theory that their interest in the basing point problem had not been publicly

${ }^{22}$ Study of Federal Trade Commission Pricing Policies, Interim Report, Sen. Doc. No. 27, 8ist Cong., Ist Sess. I (1949) (hereinafter cited as SEN. Doc. No. 27).

24 The Chairman of the Federal Trade Commission objected that with $\$ 15,000$ and a deadline of March 15, 1949, nothing like the investigation authorized by S. Res. $24 \mathrm{I}$ could be achicved. Statement of Robert E. Freer, Chairman, Federal Trade Commission, to a Subcommittee of the Senate Committec on Interstate and Foreign Commerce on S. Res. 24I, 80th Cong., 2d Sess. I (June 2, 1948) (mimeographed).

${ }^{25}$ Statement of Angus McDonald, in Small Business Committee Hearings, at $75 \mathrm{ff}$. The Committee was also described by Otis Brubaker of the United Steelworkers as a basing point business committee, although he did not suggest that it was deliberately "stacked." Senate Hearings on S. 236, at 222.

${ }^{20}$ Small Business Committee Hearings on $S$. 1008, at 76 .

${ }^{27} 95$ Cong. Rec. 9r62 (July 6, r949). Cf. Small Business Committee Hearings on S. 1008, at 80. 
expressed in recent years and that their devotion to the policies of the antitrust laws was underestimated.

None of the farm organization representatives agreed with the majority report of the advisory council. ${ }^{28}$

The center of the Committee's activities, however, was in the Committee itself. ${ }^{29}$ Its stated object was to inquire into the impact of the Supreme Court's decision in the Cement case upon consumers and small businessmen. Even this was an impossible goal, for the time was too short for any reliable indication of effect to make itself apparent. As the friendly Senate Report on the hearing stated: ${ }^{\mathbf{3 0}}$

Although many business witnesses appeared before the subcommittee and testified as to the harmful effects of required f.o.b. mill selling, it does appear that sufficient time has not yet elapsed to determine the actual effect on the cement, steel, and other industries in which that pricing practice has been adopted.

The inability of the Committee to obtain the information which it presumably was established to obtain did not prevent it, however, from compiling a record of some I,400 pages, most of it representing, to use the language of the Senate Report, "conclusions of witnesses as to what would happen to their respective businesses if f.o.b. mill pricing was required of all industry."31 Instead, therefore, of amassing testimony upon the effect of the Supreme Court decisions upon the economy, the subcommittee posed a fictitious situation (every enterpriser selling f.o.b. mill) and made a record of responses. There was no documented assertion that the existing law actually required anyone to adopt f.o.b. mill pricing.

The witnesses before the Committee represented steel customers, ${ }^{32}$ cane and beet sugar growers and refiners whose products were sold on a delivered price basis, ${ }^{33}$ candy and glucose manufacturers, ${ }^{34}$ including some under complaint by the Federal Trade Commission, cement customers, ${ }^{35}$ building materials manufacturers and dealers, ${ }^{36}$ cement producers, ${ }^{37}$ steel producers, ${ }^{38}$ railroad traffic spokesmen, ${ }^{39}$ pulp and paper producers, ${ }^{40}$ some officials of the Department of Justice and the Federal Trade Commission, ${ }^{41}$ spokesmen for trade associations in lumber, ${ }^{42}$ gro-

${ }^{28}$ Id. at 63 . The American Farm Bureau Federation neither approved nor disapproved the majority report. The National Grange and the National Farm Union representatives wrote minority reports.

${ }^{20}$ The Committee hearings were held on November 9, 10, $x x, 12,16,17,18,19,29$, and 30 ; December 6, 7, and 8, 1948 .

${ }^{30}$ SEN. DOC. No. 27 , at 35 .

${ }^{32} I d$. at $3^{6}$.

${ }^{32}$ Senate Hearings on S. Res. 241 , at $255,71,259,282,285,305,323,743,786,1075,1236$.

${ }^{33}$ Id. at $564,58 \mathrm{r}, 592,606,6 \mathrm{ro}, 64 \mathrm{I}$.

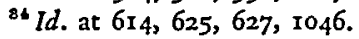

at Id. at $647,657,667,672,676,1235$.

${ }^{30} I d$. at $52,55,292,662,679,683,774$.

${ }^{37}$ Id. at $776,84 \mathrm{I}, 852$.

${ }^{28}$ Id. at 262; Pittsburgh Steel Co., id. at 505; Inland Steel Cu., $u$. at 5t4, 526, 540, 1259.

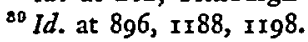

${ }^{10} \mathrm{Id}$. at 1012, 1034, 1038, 1049, 1055.

${ }^{11} I d$. at $96, \mathrm{III}, \mathrm{I27}, 142,694,790,1347$.

19. at 768 . 
ceries, ${ }^{43}$ and other commodities, small business association representatives, ${ }^{44}$ and representatives of the Army, ${ }^{45}$ Navy, ${ }^{46}$ and other federal agencies. ${ }^{47}$ A scattered representation from assorted enterprises appeared, ${ }^{48}$ and some minor public officials. Three unions were represented, one of which was a small union in the cement industry $^{49}$ and another in railroads. ${ }^{50}$ All three were from industries representing basing point interests, or benefiting from basing point systems. None of the major unions appeared, although telegrams and statements were sent by several locals. None of the principal farm organizations appeared. Big steel and cement producers were notably absent. At one point in the hearings, Senator Capehart threatened to subpoena companies in the steel industry but the threat turned out to be a request for letters answering the question whether the steel companies would return to a freight absorption sales policy "if permitted by Congress so to do." They thought they might.

One of the most interesting and important visitors was Senator Joseph O'Mahoney of Wyoming, who appeared in the company of Robert D. Pike, a spokesman for the Westvaco Chemical Company, Westvaco, Wyoming. ${ }^{52}$ Mr. Pike testified that his firm was interested in developing trona deposits in Wyoming for the purpose of producing soda ash, and that the entire investment would amount to some $\$ 25,000,000 .^{53}$ He testified that his investment might be endangered if he did not have assurance that he would be permitted to absorb and equalize freight with any competitor any place in the United States. ${ }^{54}$ Senator O'Mahoney had long been interested in developing this chemical industry in his state as a conscientious representative of Wyoming, and his appearance with Mr. Pike is evidence of the zeal with which the distinguished Senator concerned himself with the affairs of his constituents.

The hearing was a good show, with numerous witnesses to supply a chorus of protest under the direction and leadership of Senator Capehart. Although he repeatedly asserted that he wanted the facts about the effect upon industry of required f.o.b. pricing (which the law did not require), few were cross-examined except witnesses from the Federal Trade Commission, the Department of Justice, an economist from the University of Washington, and a small business group repre-

${ }^{43} I d$. at I061, Ir62.

4Id. at 29, I116, I227, 1240 .

${ }^{4} I d$. at 85,923 .

${ }^{40} I d$. at 928 .

${ }^{47}$ Reconstruction Finance Corporation, id. at 885; Bureau of Federal Supply, id. at 917, 921; Agriculture, id. at 933.

${ }^{48}$ Id. at $64,277,296,356,534,56 \mathrm{r}, 63 \mathrm{1}, 762,875,90 \mathrm{I}, 912,980,996,1079,1159,1172,1210$, I221, 1254, 126x.

${ }^{40}$ United Cement, Lime and Gypsum Workers, id. at 19, Ir48.

${ }^{50}$ Order of Railway Conductors, id. at 1206; Glass Bottle Blowers Association of the United States and Canada, id. at $97 \mathrm{r}$.

${ }^{61} I d$. at 1374 .

EI Id. at 949 .

${ }^{53}$ Id. at 955 .

${ }^{5}$ Ibid. 
sentative, all of whom testified either that the law didn't require f.o.b. pricing or that they thought that it would be a good idea if it did. Harmony prevailed in the relations between the subcommittee, its chairman, and all other witnesses. With the skill of a conductor on the podium, Capehart led witness after witness (once their prepared statements were out of the way) through a series of questions that made it appear that enterprisers were confused by the existing law, that they had no place to go in the government for a definitive answer, and that it was necessary for Congress to come to their rescue and write legislation on the subject. He was his own best witness, and he spoke to the record through many voices. He finally worked himself around to the view that the Cement case of I948 was a boon to United States Steel, ${ }^{55}$ the larger steel companies, and big business, ${ }^{\mathbf{5 6}}$ and that he was defending the little businessman, presumably by "forcing" the steel industry to stop f.o.b. pricing. ${ }^{57}$ The representative from Inland Steel lent a hand to this piece of dramaturgy by saying that f.o.b. pricing would be to the advantage of the steel industry but that he opposed it because it would stifle competition and lead to monopoly. ${ }^{\text { }}$ One of the more imaginative speculations about the consequences of required f.o.b. pricing was Capehart's suggestion to a witness that it was injurious to health, because more people would be poisoned by "smog" created by concentrated industries-concentration being an alleged consequence of required f.o.b. pricing. ${ }^{60}$

In matters of substance, the Capehart hearings produced a potpourri of paradoxes and contradictions. Big business wanted new legislation but small business enterprisers argued their case for them. The normal competitive advantage of low freight cost (nearness to mills) was represented as offensive monopoly. The industry wide system of uniform delivered prices which lends itself to the curtailment of price competition under conditions of conspiracy or conscious parallelism, was called competition. It was argued that local monopolies would be produced unless a pricing system which produced national monopolies was restored. Although all producers offer the same buyer one price under some forms of the basing point delivered price system, the Federal Government was assumed to be doing the same thing when it sells stamps for three cents everywhere, even though the Federal Government is one producer charging the same price to every buyer. Little business asked the Congress to "permit" them to employ a system (freight absorption) which works to their disadvantage more often than to their advantage since, by being small, they often do not have the resources to compete in a national market. In the interest

${ }^{65} I d$. at $34 \mathrm{I}$.

"Id. at 347 .

${ }^{87} I d$. at 563 . See also Senate Hearings on S. 236 , at 224 , where Senator Capehart said that he thought "that the big steel industries would welcome a law making it illegal to sell on any other than f.o.b. basis." If one assumes with Senator Capehart that the FTC and the courts already required f.o.b. pricing, it would appear that the steel companies should have supported the Federal Trade Commission. The record does not indicate such support.

${ }^{\mathrm{CB}}$ Senate Hearings on $S$. Res. $24 \mathrm{I}$, at $5 \mathrm{I}_{4} \mathrm{ff}$.

${ }^{60} \mathrm{Id}$. at 510 . On this point the colloquy concluded as follows: "Senator Capehart. So we might add health. Mr. Beeson. I would like to add health." 
of clarity, the Capehart Committee laid the foundation for new legislation that would take years to litigate.

One jarring note in the proceedings was supplied by the persistent off-stage racket of Congressman Wright Patman of Texas, who took a disrespectful view of the entire affair. The Senator from Indiana heckled the Congressman from Texas, in absentia, when a Texas steel producer testified that he was confused by the law on pricing, that the uncertainties of the law should be cleared up, and that Congress should do the clearing. ${ }^{60}$ Capehart and the steel man agreed that the steel man knew more about steel than Congressman Patman. ${ }^{61}$ The Democratic National Committee made releases of some of Congressman Patman's charges that the subcommittee was a big business committee and that the hearings were a not too covert attack upon the antitrust laws. The rumor got about that the Democratic National Committee itself would make an official statement at the behest of the "high policy makers in the Democratic Party," but Senator McMahon scotched the rumor. ${ }^{62}$ Capehart finally took official notice of the activities of Congressman Patman by inserting into the record a release bearing the heading of the Publicity Division of the National Democratic Committee. ${ }^{63}$ The release contained the text of Congressman Patman's charges, with many citations from the press, including a Wall Street Journal report of an interview with a leading steel company president to the effect that a multitude of steel customers would get farther than a few big steel companies in the movement to change the law. ${ }^{04}$ Capehart made an attack upon Patman in the hearing, charging him with making misstatements, and with being unfair. The advisory committee, he said, was not "stacked" but had been selected because of the knowledge of the members of the subject. Capehart specially mentioned the union and farm representatives. He was particularly annoyed by the Patman statement, issued after the election in November, 1948 , that, ${ }^{65}$

If Republicans had gained control of Congress and the Presidency, the anti-trust laws would have been repealed in 30 days and organized greed would have been in complete charge of the country.

This piece of political extravagance seemed to produce a stronger reaction than it deserved. Senator Capehart waved it in front of a subsequent witness who said appropriate and soothing things. ${ }^{66}$

\section{III}

The Evolution of S. 236

The election undoubtedly had some influence upon the plans of those who wanted Congress to write new legislation on the subject of pricing policies. ${ }^{67}$ With

${ }^{80}$ Statement of Ralph L. Gray, id. at 540-54r.

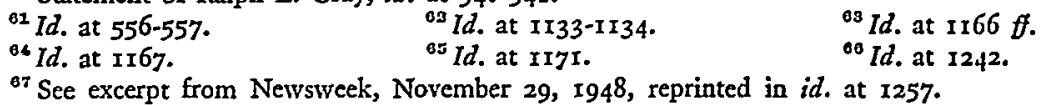


a change in the political complexion of the House and the Senate, the committee memberships were reshuffled and Capehart lost his chairmanship. ${ }^{68}$ Those who assumed that the subcommittee would be making its report to a friendly and well disposed Congress were faced with a Congress of unpredictable temper. As events showed, however, the movement to write a new law went far in the new Congress and, indeed, was halted only by the tireless efforts of a small group of Senators led by Kefauver of Tennessee, Long of Louisiana, and Douglas of Illinois.

Before any report could be made to the Senate on the original Capehart Resolution (S. Res. 24I), Senator Capehart, and Senator Johnson of Colorado who succeeded Capehart as chairman of the subcommittee, introduced a bill on January 5 , I949 to make permanent amendments to the Federal Trade Commission Act and the Clayton Act, as amended by the Robinson-Patman Act. The bill was referred to the Committee on Interstate and Foreign Commerce which proceeded, through the subcommittee headed by Johnson, to hold hearings. ${ }^{69}$ At the least, this effort to secure permanent legislation before the investigating committee had reported showed haste, and justified the feeling that the sponsors were in an unseemly hurry. The bill of Senator Johnson was understood by Secretary of Commerce Sawyer to have the purpose of "preserving the existing status of regulation as businessmen generally understood it to be prior to the opinion in the Cement Case."70 It had taken almost eleven years to get the Cement case decided. ${ }^{71}$ While regulation walked with tortoise speed, relief from regulation was to fly on wings.

The proposed bill would have amended the Federal Trade Commission Act by outlawing any price fixing conspiracy or combination. This was surplusage since they were already illegal under the Cement case and other cases. In the absence of such agreement or conspiracy, no pricing practice was to be deemed an unfair method of competition because the delivered price was uniform on goods of like quality and grade, or was similarly uniform within any geographical zone, or absorbed freight. Practices tainted with fraud, deception, or coercion were denied the benefit of the amendment. The justifications available to a seller charged with practicing discriminatory pricing under the Robinson-Patman Act were increased. Prices lower than those of a competitor were exempted from the prohibitions of the Act where the differential was customary in the general price relationships of the respective products or "otherwise justified by the competitive situation of the

\footnotetext{
${ }^{08}$ Senator Johnson took over Senator Capehart's job as chairman on January 3, 1949. See Senate Hearings on $S$. 236 , at 223. This did not mean a change in leadership, however, for the record shows that Senator Capehart did most of the talking on the Subcommittee side after the reshuffle.

${ }^{\circ 0}$ Senate Hearings on $S$. $23^{6}$, at 2. The hearings were held for only three days in January and one day in February. The February meeting was held for the purpose of amending S. 236 before transferring jurisdiction over the bill to the Senate Committee on the Judiciary.

${ }^{\circ} \mathrm{Id}$. at 5 .

${ }^{71}$ Secretary Sawyer in no way proposed that the decision in the Cement case as it related to conspiracy was to be modified. Ibid.
} 
two or more sellers." T2 The authority of the Federal 'Trade Commission to require remedial action to dissipate the effects of a conspiracy was expanded.

Two people from federal agencies who had testified in the Capehart hearings appeared to testify in the brief hearings on S. $236 .^{73}$ Some new witnesses appeared to express a point of view different from the standard patter of confessed confusion, helplessness to choose acceptable pricing courses, and desire for Congressional relief. ${ }^{4}$ Business groups, of course, were represented, among them being the Chamber of Commerce, ${ }^{75}$ the National Canners Association, ${ }^{76}$ National Retail Lumber Dealers Association, ${ }^{77}$ and local and state chambers and industrial associations. ${ }^{78}$ Counsel for food and private truck owners associations, ${ }^{70}$ the American Bar Association, ${ }^{80}$ and private witnesses ${ }^{81}$ expressed the hope that Congress would do what was called for, although the witness for the truckers and the food dealers thought that Congress should be careful. ${ }^{82}$ The chief witnesses, however, were the chairman of the Interstate Commerce Commission who wanted references to his agency stricken, $^{83}$ a group of witnesses from the Federal Trade Commission, and the research director for the United Steelworkers of America.

In the course of the questions put to the chairman of the Interstate Commerce Commission, it appeared that the questioners seemed less interested in the witness' problem than in trying to make it appear that the Interstate Commerce Commission promotes freight absorption ${ }^{84}$ in order to encourage competition. The ICC on occasion permits blanket rates in order to allow sellers in two parts of the country to compete in the same market from which they are not equidistant. This produces a version of freight absorption in as much as the price to the consumer is not

${ }^{72}$ Id. at 3 .

${ }^{73}$ These wcre Herbert A. Bergson, Assistant Attorney General, Antitrust Division of the Department of Justice, id. at 74, and Allen C. Phelps, lawyer and Chief of the Export Trade Division of the Federal Trade Commission, id. at 60.

${ }^{74}$ Among the new groups were the United Steelworkers of America, represented by its Research Director, Otis Brubaker, id. at 185 , and the National Farmers Union represented by Angus MacDonald, Assistant Legislative Secretary, id. at 136 . The National Grange appeared through J. T. Sanders, id. at 243 .

${ }^{70} I d$. at 168.

${ }^{70} I d$. at 33 .

${ }^{77} I d$. at 55 .

${ }^{78}$ Id. at II 8, I3I, III.

${ }^{79} 1 d$. at 235.

${ }^{80}$ Id. at 49. See also American Bar Association resolution in support of Congressional intervention, id. at 316 .

${ }_{81}$ Id. at 176,163 .

${ }^{83}$ Id. at 236 .

${ }^{83} \mathrm{He}$ was concerned lest one of the stated policies of the bill-"to foster competitive private enterprise by the treatment of transportation costs in interstate commerce so that access to distant markets may be available, when economically feasible, to any competing seller"-be construed to alter the jurisdiction of the Interstate Commerce Commission. He felt that it would be difficult for the Commission to determine economic feasibility and that it would lay a ground for attack upon its decisions by "disappointed litigants who might charge that they were denied access to distant markets by the Commission's action." He suggested that the reference to the Interstate Commerce Commission be deleted and indicated that he thought that the basic legislation under which the ICC operates adequately provided for consideration of the element of competition in rate making. Id. at 7-9.

${ }^{84}$ Id. at I4-15. 
the sum of the cost of production and shipping. Commissioner Mahaffie refused to say that this practice was the same as freight absorption with which the Subcommittee was concerned, in spite of insistent prodding by Senator Capehart. ${ }^{85}$ He did express his personal view that the "prohibition of any (i.e., all) absorption would be disturbing to business." 86 Capehart chose to regard this answer as an endorsement of his effort to prevent the Federal Trade Commission from requiring all sellers to adopt f.o.b. pricing, which was the theme of the Capehart hearings, but was not the law as it existed, nor the express policy of the Federal Trade Commission.

The witnesses from the Federal Trade Commission were Ewin L. Davis, Commissioner, and a group of Commission lawyers. ${ }^{87}$ Missing from this group was Walter Wooden, Associate General Counsel of the Commission, who in the hearings on S. $24 \mathrm{I}$ had been subjected to a stiff cross examination by Senator Capehart and counsel for the Capehart Committee because he felt that f.o.b. pricing, although not the law, was desirable policy. The first presentation was made by Commissioner Davis, who took note of widespread misapprehensions that had followed the Cement case in April I948, but thought that the misapprehension was abating. ${ }^{88}$ He made the suggestion that Congress, by refusing to change the existing law, would do much itself to abate such confusion as might remain. ${ }^{80}$

Since the original drive to change the law was supposed to have been caused by the confusion among businessmen and their lawyers as to the meaning of the law and the intentions of the Federal Trade Commission, Commissioner Davis proceeded to show that the Commission had issued statements in explanation on two occasions and stood ready to issue further ones to clear up still obscure matters. $^{90}$ In its reply to the questions put by the Chamber of Commerce of the State of New York, dated January 12, I949, the Commission had refused to say that all basing point systems were violations of the law, or to predict all of the circumstances in which conspiracy might be proved. The Commission was specific in saying that it did not advocate required f.o.b. pricing. ${ }^{91}$ In his testimony, Commissioner Davis was equally specific in saying that a seller could absorb freight or absorb part of his manufacturing costs or any other costs in order, in good faith,

${ }^{\text {BE } I d . ~ a t ~ I 5-I 8 . ~}$

${ }^{80} I d$. at $2 \mathrm{r}$.

${ }^{87}$ Allen Phelps, Assistant Chief Trial Counsel and Chief of the Export Trade Division of the Federal Trade Commission; Robert B. Dawkins, Special Legal Assistant to the Federal Trade Commission; and Joseph E. Sheehy, Associate Director of the Bureau of Legal Investigation of the Commission.

88 Id. at 23.

80 lbid.

${ }^{\circ} \mathrm{FTC}$, Notice to the Staff, In Re: Commission Policy Toward Geographic Pricing Practices (Oct. 12, 1948); FTC Release, Letter from Commission to Secretary of Chamber of Commerce of State of New York, January 12, 1949. Senate Hearings on S. 236, at 24.

${ }^{01}$ Commissioner Davis was emphatic in pointing out that "The Commission has not in a single case challenged the use of the basing point method of pricing per se, separate and apart from collusion. The Commission has not challenged freight absorption per se. The Commission has not required f.o.b. mill pricing. The Commission has not challenged the legality of the use of uniform delivered prices by an individual concern." Senate Hearings on $S .236$, at 24 . 
to meet an equally low price of a competitor. ${ }^{92}$ As to the proposed legislation, he was of the view that it was neither necessary nor desirable. ${ }^{03}$ Commissioner Davis later gave to the Subcommittee the views of a majority of the Commission on fiftyfour questions dealing with Commission policy. ${ }^{94}$ Apart from the propriety of using a public hearing to force from a quasi-judicial agency an assurance as to future policy, the Commission statement should have been sufficient clarification for all but the willfully self-confused.

Commissioner Davis commended to the attention of the Subcommittee two FTC lawyers who had been requested to appear (Sheehy and Dawkins). ${ }^{95}$ Both expressed objections to S. 236. Dawkins echoed the view of Commissioner Davis that the rash of uncertainties was subsiding under the influence of public discussion, and that S. 236 would not reduce uncertainty but would increase it by the use of new and ambiguous concepts and words that would require long litigation. ${ }^{.0}$ Another lawyer, however (Phelps), contradicted Commissioner Davis, ${ }^{07}$ thought that there was a drive to impose f.o.b. pricing on all sellers, ${ }^{98}$ and felt that Congress should act.99 The chairman of the Subcommittee thanked him for his "scholarly presentation." 100

Differences of view expressed by the witnesses from the Federal Trade Commission, however, lent leverage to the Subcommittee in its claim of excessive uncertainty and confusion arising out of the Cement case. In the Interim Report to the Senate on S. 236, the contradictory statements of the FTC witnesses were laid end to end, and pronounced "confusing."101 They were actually made to appear more confusing than they would have been, had the Subcommittee heeded the explanation made by Commissioner Davis. He later pointed out that all of the individuals had been invited in their personal capacities, that they had so testified, and then said: ${ }^{102}$

The Commission regards difference of opinion among staff members and even among Commissioners as a normal incident of the development of policy and of the interpretation of law; and believing that responsible interpretations of public questions contribute to the understanding thereof, the Commission is unwilling either to require all staff members to express only its official views or to muzzle all staff members who think for themselves. ${ }^{103}$

${ }^{92} I d$. at 25 .

${ }^{93}$ Id. at 26 .

"1 Id. at 268-278. These replies constituted a clear answer to legitimate questions of doubt about the policies and expectations of the Commission.

${ }^{95}$ Id. at 27.

${ }^{98}$ Id. at 97.

${ }^{97} \mathrm{Id}$. at 65 .

${ }^{98} I d$. at 66 .

${ }^{90} I d$. at 67 .

${ }^{100} \mathrm{Id}$. at 69 .

101 SEN. DoC. No. 27 , at $46 f$.

${ }^{203}$ Senate Hearings on $S .236$, at 275.

${ }^{103}$ The reference to disagreements among the members of the Commission is documented by the record of the hearings on S. 236. On February 18, 1949, Senator Johnson wrote to Commissioner Lowell Mason, who replied March 2, I949 that he wished to express his disagreement from the majority of the Commission on matters before the Congress. Id. at 337-338. 
It may be said at this point that the Subcommittee under both Capehart and Johnson seemed interested in obtaining assurances that the Commission would not press the enforcement of the law rigorously in the directions which the Supreme Court had indicated were open. Capehart had previously referred to meeting with representatives of the Commission for the purpose of coming to some understanding..$^{104}$ At the time of the hearings on S. 236 , however, the record did not show that such an understanding had been negotiated and much, therefore, was being made of the contradictions. Subsequently the Subcommittee took credit for producing mollifying disclaimers by the Commission and for the Commission's acceptance of the views of Commissioner Davis, ${ }^{105}$ although even then it was still felt necessary to enact legislation to be sure that the Commission did not backslide.

One of the most thoroughly prepared presentations made to the Johnson Committee was that of Otis Brubaker, research director for the United Steelworkers of America. ${ }^{100}$ It offered evidence, instead of speculation, that the effects of the Cement case allegedly feared were not taking place. Throughout the entire thirty districts of the USWA "we found not one single basic steel plant or one steelfabricating plant which had been shut down because of the pricing change."107 In the questioning of Brubaker after his direct statement, however, there was no effort to test the validity of his findings. Rather, Capehart undertook to swoop him off into the empyrean of speculation-to a fictitious world where the only pricing alternative is required f.o.b., to a realm "where the big steel industries would welcome a law making it illegal to sell on any other than f.o.b. basis."108 The conclusion is permissible that the Subcommittee was more interested in proving its case than in hearing it refuted.

There was a hiatus between the third and the fourth of the four days of hearings on S. 236, a hiatus of about three weeks. In this period of time a change in strategy took place. Senators Johnson and Capehart were still pushing for permanent legislation, and Johnson instructed subcommittee counsel to revise the bill. Subcommittee counsel met with Commissioner Davis, who reportedly instructed the Federal Trade Commission staff to collaborate with subcommittee counsel in the preparation of a revised bill. Johnson approved the revision and told Commissioner Davis that he would accept the revision and try to get it through Congress "if the Commission formally approved the bill."109 Commissioner Davis replied that the Commission opposed any legislation, and that it would not approve the bill. An amended S. 236 was nevertheless prepared. It was said by the chairman

\footnotetext{
104 Senate Hearings on S. Res. $24 \pi$, at ror.

${ }^{105}$ SEN. Doc. No. 27 , at 63.

${ }^{108}$ Senate Hearings on $S$. 236 , at $185 \mathrm{ff}$. The record of the study and the testimony of the representative of the United Steclworkers was of importance in as much as it supplied some of the basis for the attack upon the movement to obtain Congressional relief which was made by Senator Wayne Morse, 95 Cong. Rec. 7162, 7I64 (May 3I, 1949).

${ }^{107}$ Senate Hearings on $S .236$, at 202.

${ }^{208}$ Id. at 224.

${ }^{100}$ SEN. Doa. No. 27 , at 69-70.
} 
of the Subcommittee to have embodied the advice of Assistant Attorney General Bergson at many points. ${ }^{110}$

In the amended bill, the references to the Interstate Commerce Commission which were uncongenial to the chairman of that body were eliminated. Provisions of the bill would have made it harder for the Federal Trade Commission to prove any violation of the antitrust laws in the absence of conspiracy, and even the value of some of the evidence that would tend to prove conspiracy was reduced. The original aim of the bill was intact and indeed strengthened, to wit, to enact a permanent amendment to the antitrust laws on the basis of the Capehart testimony, which was largely ex parte, and the three days of hearings under the nominal chairmanship of Senator Johnson.

\section{IV}

\section{The Myers Moratorium}

Although S. 236 had been amended as a result of the hearings, the effort to get it adopted was abandoned ${ }^{111}$ and support was given instead to a bill which Senator Myers of Pennsylvania had introduced before the hearings on S. 236 were finished: a bill to provide a legislative moratorium. ${ }^{112}$ This bill, S. 1008, was referred to the Senate Committee on Interstate and Foreign Commerce, of which the JohnsonCapehart Subcommittee was a part. Under the Legislative Reorganization Act of I946, amendments to the Federal Trade Commission Act were put under the jurisdiction of the Committee on Interstate and Foreign Commerce, while amendments to the Clayton Act were under the jurisdiction of the Committee on the Judiciary. Ten days after the hearings on S. 236 , Senator Johnson introduced a resolution to transfer jurisdiction of both S. 236 and S. I008 from the Committee on Interstate and Foreign Commerce to the Committee on the Judiciary, and this was approved by the Senate. ${ }^{113}$

${ }^{110} I d$. at $64-69$, passim.

111 Several factors led to this change in strategy. First, the Subcommittee had failed to get Federal Trade Commission approval of the proposed legislation. This failure to approve could have lessencd the chances of passage. Second, Assistant Attorney General Bergson in a speech before the New York City bar on February I7 had said that he had opposed S. 236 because it provided permanent regulation of a subject then being adjudicated, but indicated that he would not be adverse to a moratorium that would permit Congress time to develop satisfactory permanent legislation, if any should be found to be needed. Id. at 71 . Third, it appeared that considerable time might pass before Congress would adopt S. 236, if it ever did. The chances of getting a quick moratorium that would produce the same result for a shorter time then appeared to be qutic attractive.

${ }^{112}$ Representative Walter of Pennsylvania introduced a similar bill in the House at the same time, H. R. 2222. In a speech to the Chicago Association of Commerce and Industry, Senator O'Mahoney said that S. 236 was abandoned because "so uncertain were the members of the committee of what the effect of that bill would be that they decided not to report it and instead to report a bill which was called the 'moratorium bill.'" 95 Cong. Rec. A4289, A4290 (June 28, 1949). The clarifiers in short were confused.

${ }^{113}$ S. Res. No. 76, 95 Cong. Rec. I6r5 (Feb. 28, 1949). According to Senator O'Conor of Maryland, the moving spirit in the transferring of jurisdiction was Senator McCarran of Nevada. 95 Cong. Rec. 7156 (May 3I, r949). 
Before any hearings were held on the Myers Bill (S. I008), the Committee on Interstate and Foreign Commerce made an Interim Report to the Senate on the original Capehart hearings, the hearings on S. 236 as amended, and on S. Ioo8..$^{114}$ The Interim Report, which more nearly resembled a thesis than a report, was an argumentative attack upon the Federal Trade Commission. Attention was given to the plight of those who, under required f.o.b. pricing, would not be able to relocate their plants or build a $\$ 300,000,000$ steel mill. ${ }^{115}$ Out of pages of testimony by the United Steelworkers representative, the part which the authors of the Interim Report salvaged was a statement saying that a straight f.o.b. system was as undesirable as a straight basing point system. The same witness also said that the law did not require f.o.b. pricing, and that no legislation, therefore, was needed to allow freight absorption. On the other hand, a considerable amount of space was given to the testimony of the small number of unions who were basing point beneficiaries. There were tears for the proverbial victims of government regulation, "the small investor, widow, or orphan" who would "have unpleasant surprises with no fair warning."116 The ambiguous surprises were evidently related to an asserted stock market decline in the securities of companies struck foul by the pricing policy which the Federal Trade Commission said it was not enforcing. Various statements of the staff of the Commission were examined for inconsistency with pedantic fidelity. Painstaking research was evident in the historical exposition of the Commission's well-known view that conspiracy is a bad thing and that basing point systems lend themselves to violations of the antitrust laws. The good faith of the Commission was challenged in the statement that, ${ }^{117}$

The Commission's present disclaimer of any intention to require f.o.b. mill selling, and current confusion as to the legality of competitive freight absorption, may be examined in the light of this historical background.

Although no hearings had as yet been held on S. 1008, the hope was voiced that S. 1008 would be passed immediately by Congress $^{118}$ while further consideration was given to S. 236 .

There were three days of hearings on S. 1008 at the end of March and the first of April, I949. The bill itself was very simple. ${ }^{119}$ The intent was disclaimed to

${ }^{114}$ SEN. Doc. No. 27, 8ist Cong., Ist Sess. (1949).

$110 \mathrm{Id}$. at $2 \mathrm{I}$.

${ }^{210} \mathrm{Id}$. at 27.

${ }^{117} I d$, at 45 .

${ }^{118} \mathrm{Id}$. at 72.

110 See Senate Hearings on S. roos, at I. Section I of the Myers bill declared "that it has not been the intent of the Congress to deprive individual companies of the right to use delivered price systems or to absorb freight to meet competition in any or all markets, provided such activities are carried on independently and in good faith, and not through any combination or conspiracy in violation of the Sherman Act as amended." Section 2 provided as follows: "Until the expiration of two years after the enactment of this Act, the Federal Trade Commission Act, as amended, and the Clayton Act, as amended, shall not be construed as depriving individual companies, in the absence of conspiracy or combination or other agreement in restraint of trade, of the right to independently use delivered price systems or to absorb freight to meet competition in any and all markets." Section 3 provided that "Nothing herein contained shall affect any proceeding pending in any Federal court of the United States on February $I$, 1949." 
deprive individual companies of the right, independently, to use delivered price systems or to absorb freight to meet competition in any and all markets, provided good faith was present and conspiratorial design was absent. One part of the bill provided that for two years the Federal Trade Commission Act and the Clayton Act (both as amended) should not be construed as depriving individual companies of the right, independently, to use delivered price systems or to absorb freight to meet competition in any and all markets, so long as there was no conspiracy or combination to restrain trade. The scene of action was now the Subcommittee of the Committee on the Judiciary, and the cast of characters had changed. The three members of the Subcommittee were McCarran of Nevada, O'Conor of Maryland, and Wiley of Wisconsin.

The Senate Judiciary Committee hearings on S. 1008 were notable chiefly because the CIO as an organization appeared for the first time to object to the rate and the direction in which the move to write legislation was proceeding; the Federal Trade Commission took a clear position through one spokesman; and several members of Congress also testified. The spokesman for the CIO was the research director for the United Steelworkers of America who had appeared in the hearings on S. $236 .^{120} \mathrm{He}$ objected both to the idea of a moratorium and to the language of the proposed bill, feeling that the Supreme Court's expected decision in the Rigid Steel case might dispose of many points said to be controversial, and that the Myers Bill was vague enough to permit the reestablishment, entire, of the steel industry's pricing practices before the Cement case of 1948 . He called attention to the study he had presented to the Johnson Committee, ${ }^{121}$ felt that the Commission had settled the matters about which confusion was said to exist, ${ }^{122}$ described how steel union locals were being solicited by steel companies to support S. 236 and S. $1008,{ }^{123}$ and pointed out that stockholders were being urged to write their Congressmen to the same effect. ${ }^{124}$

The Federal Trade Commission view was represented by the Associate General Counsel who had testified before the Johnson Committee on S. $236 .{ }^{125}$ The views he expressed were those of the Commission, with one dissent. ${ }^{126}$ The dissent was included in the record in the form of a communication to Senator Johnson. ${ }^{127}$ The Commission view in brief was that the adoption of the moratorium would increase any confusion that might exist as to the meaning and application of the Federal Trade Commission and Clayton Acts. ${ }^{128}$ Although specific weaknesses of S. 1008 might be cured by amendment and revision, the Commission's objection went to the very idea of the moratorium itself, since any such moratorium would inevitably

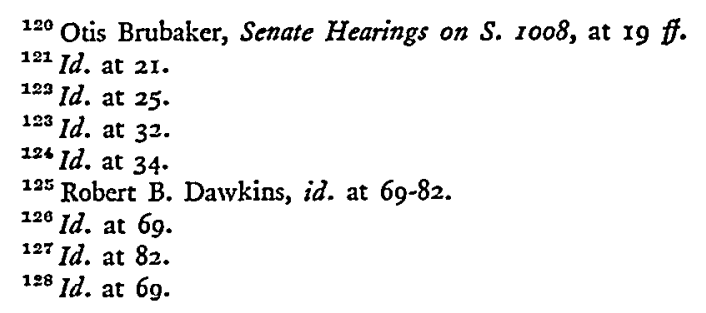


create a basis for further and additional uncertainties. ${ }^{129}$ The Commission witness also felt that the Supreme Court might in the Rigid Steel Conduit case then pending clear up many matters about which uncertainty had been expressed.

The members of Congress who testified were Senators Myers and Johnson, and Representative Walter of Pennsylvania. Senator Myers of Pennsylvania, like the Commission and CIO witnesses, indicated that he was looking forward to the Supreme Court's decision in the Rigid Steel case before considering permanent legislation. ${ }^{130}$ The Myers moratorium had been proposed, said the Senator, because the Johnson Bill (S. 236) dealt with a matter too complex for the Congress to dispose of in speedy fashion. ${ }^{131}$ Although the Myers Bill suggested a two year moratorium, he was not insistent on this term. ${ }^{132}$ Senator Johnson of Colorado took a short time to bring the record of alleged Commission inconsistencies up to date, including witnesses as recently as the day before, in the mood and the manner of the Interim Report which bore his name. ${ }^{133}$ His most original contribution was a classification which divided those who want to encourage competition, and those who want no competition, with the Federal Trade Commission and the Supreme Court in the second category. ${ }^{134}$ Representative Walter of Pennsylvania supported the proposed bill since he had introduced one like it in the House. ${ }^{135}$ There were other witnesses, some of whom had appeared before the Capehart and Johnson Committees. ${ }^{130}$ One of them, at least, seemed to have got into the wrong hearing because he wanted to talk about advertising allowances as they affected dress manufacturers, and thought that since moratoriums were in order, one might be fashioned for his problems. He indicated that he would settle for advisory opinions by the Federal Trade Commission "or somebody."137

$\mathrm{V}$

\section{“. . . Ggography Counts a Lot in Politrics"138}

On April 27, the Myers Bill was reported favorably to the Senate, with an amendment. ${ }^{139}$ The moratorium period was fixed by date (July I, I950), and there were changes in language designed to restrict the operation of the moratorium to

${ }^{120} I d$. at $\mathrm{gr}$.

${ }^{130}$ Id. at 5.

231 Ibid.

${ }^{139} I d$. at 7 .

${ }^{13 a}$ Id. at $85-89$.

${ }^{134}$ Id. at 86.

${ }^{135}$ Id. at 8.

${ }^{130}$ See, for example, George Burger, National Federation of Small Business, id. at 45; Angus MacDonald, National Farmers Union, id. at 59. See also American Steel Warehouse Association, id. at 95; Order of Railway Conductors, id. at 82; General Counsel Senate Subcommittee on Trade Policies, id. at 89. ${ }^{137}$ Id. at 14 .

${ }^{138}$ Senator Wiley, id. at 79 .

${ }^{130}$ Sen. Rep. No. 305, 81st Cong., Ist Sess. (1949), 95 Cong. Ree. 5186 (April 27, 1949). Even as amended, the bill was regarded by the Federal Trade Commission as neither necessary nor desirable. Sec letter from the Commission to Congressman Patman of Texas. 95 Cong. Rec. A3524-A3527 (May 3r, 1949). 
the practice of freight absorption, without giving countenance to the systematic use of basing point pricing. For example, the phrase "quote and sell at delivered prices" replaced "use delivered price systems." An appendix to the bill contained a brief citation of Supreme Court cases tending to uphold the constitutionality of legislative overriders of Supreme Court cases, and it was the judgment of the Committee on the Judiciary, speaking through Senator O'Conor, that S. 1008 was within the constitutional authority of Congress to enact. There was, however, no statement as to the Supreme Court decisions which S. 1008 was setting aside. Senator Langer of North Dakota dissented from the Committee report and recommendation, ${ }^{140}$ because the bill introduced at least four new terms and phrases in the antitrust laws without defining them. ${ }^{141}$ It would, he said, have the practical effect of immunizing various monopolistic practices which the supporters of the bill would condemn; it would vitiate enforcement of the antitrust laws by substituting intent for practical effect as a test of violation; and it would legalize basing point systems and phantom freight through the uses that can be made of freight absorption. Senator Langer concluded that Congress was invading the sphere of the judiciary, and recommended that Congress either refuse to pass the bill, or amend it further to protect the antitrust laws. ${ }^{142}$ His dissent from the majority report of the Senate Committee on the Judiciary laid the foundation for a strong attack upon the bill when it came up for debate.

It came up for debate on May $3 \mathrm{I}$ when Senator Myers moved its consideration. ${ }^{143}$ Those who might have been opponents of the legislation, those who might have argued that Congress should let the Supreme Court work out the clarification of any possible confusion, were disarmed by the Court itself. One hour after the Senate Judiciary Committee had voted $7-2$ to report the Myers Bill favorably to the Senate, the Supreme Court handed down its decision in the Rigid Steel case. ${ }^{144}$ The Court had split four to four. ${ }^{145}$ A half hour before the Myers Bill was to come up for debate Senator O'Mahoney of Wyoming talked with Myers and others about a substitute bill that he wanted to introduce in place of the one that the Committee on the Judiciary had worked on. ${ }^{146}$ An arrangement was made to permit O'Mahoney to discuss his proposed substitute before final vote on the Myers Bill. Senator O'Conor assumed charge of the Myers Bill, and the Senate proceeded

\footnotetext{
${ }^{140}$ SEN. ReP. No. 305, pt. 2, 81 ist Cong., ist Sess. 5 (1949).

141 These were "engaging in competition"; "absorb freight"; "in any and all markets"; and "delivered prices."

${ }^{142}$ See note 140 supra.

14395 Cong. Rec. 7155 (May 31, 1949).

144 Id. at 7r59. Triangle Conduit \& Cable Co. v. Federal 'Trade Comm'n, I68 F. 2d 175 (C. C. A. 7th 1948), aff'd per curiam sub nom, Clayton Mark \& Co. v. Federal Trade Comm'n, 336 U. S. 956 (I949).

145 "Perhaps as a result of this split decision sentiments in the Senate in favor of permanent legislation in preference to a moratorium appears to have strengthened." Testimony of Herbert A. Bergson, Assistant Attorney General, in $H$. R. Hearings on $S$. 1008, at $1 \mathrm{r}$.

${ }^{143}$ This was S. 1974, which was referred to the Committee on the Judiciary. 95 Cong. Rec. 7137 (May 3r, r949).
} 
to consider the measure which was now moot because of the expected O'Mahoney substitution.

O'Conor's opening statement in explanation of the bill described the principal features of the measure. He was not accurate in making a strong implication that mere freight absorption as such was unlawful, or that the only pricing alternative available to businessmen under the law was f.o.b. pricing. ${ }^{147}$ There was widespread confusion, he said; the expected "clarification" by the Supreme Court in the Rigid Steel case had not materialized; and it was now even more necessary than ever for Congress to intervene. The intervention prescribed by $\mathrm{S}$. 1008 was a moratorium until July $\mathrm{I}$, $\mathrm{x} 95^{\circ}$, on all proceedings against pricing practices except those where conspiracy or combination was involved. There was to be no permanent change in the law, and Congress was not committing itself to any particular course of action or policy after the expiration of the moratorium. He made a point of saying that the bill was not a "big business" bill but one that involved the entire economy. ${ }^{148}$ Following the explanation, Senator Langer of North Dakota launched an attack on the bill, in the main following the points that he had raised in his dissent from the Senate Judiciary Committee Report on S. roo8, but adding new matter of a general nature, in a text full of personal reminiscences. ${ }^{149}$

The principal attack in this opening phase of the debate on S. Ioo8 was made by Senator Wayne Morse of Oregon. ${ }^{150} \mathrm{He}$ described the cross-pull and interplay of pressures working upon Congress, master-minded, he asserted, by the steel companies. The steel decision to go to f.o.b. pricing was not forced by the Cement case because, as the Small Business Committee had reported in 1948 before the Cement case, there had been a steady withdrawal of steel away from those markets where freight was absorbed. ${ }^{151}$ The Cement case provided a pretext to the steel companies to get rid of costly freight absorption in a sellers market, he said, and shift the blame for the change to the Federal Trade Commission. Moreover, this maneuver transformed steel buyers into an "army of zealous supporters of the modification of the law which the steel industry desired." ${ }^{2} \mathrm{He}$ charged deliberate misrepresentation of the Federal Trade Commission's position on these matters and denied that the record showed any ambition on the part of the Commission to force enterprises to adopt f.o.b. pricing. He cited evidence to show that on June 2, 1948, at the outset of the controversy, and in January, r949, the position of the Federal Trade Commission had been clear that the Cement case did not outlaw all delivered prices or require only f.o.b. prices. ${ }^{153} \mathrm{He}$ asserted that the propaganda line in favor

${ }^{147}$ See 95 Cong. Rec. 7158 (May 31, 1949), where Senator O'Conor used language that made it appear that the Federal Trade Commission felt that the Cement case made freight absorption unlawful. He did not cite the express denial of this made by Commissioner Davis and referred to above.

${ }^{148} \mathrm{Id}$. at 7159 .

${ }^{100} \mathrm{Id}$. at $7160 \mathrm{ff}$.

${ }^{150} \mathrm{Id}$. at $7162-7169$.

${ }^{101} I d$. at 7164 .

${ }^{103}$ Ibid.

${ }^{163}$ See p. 283 supra. 
of revision of the laws was perfected in the summer of 1948 . The offensive phrase "basing point" was discarded and the pricing practices of the steel industry were represented as being no more than absorption of freight where necessary in order to meet competition. ${ }^{154}$ It was his conclusion, as it had been that of Senator Langer, that the blanket authorization in S. I008 to absorb freight for the sake of quoting identical prices would legalize the entire mechanism of the basing point system. ${ }^{105}$ Langer had begun his speech on May $3^{\mathrm{r}}$. He yielded to Morse so that the latter could get his speech in before he made a train. Langer resumed his remarks the next day, finishing his attack upon S. 1008 as sponsored by Myers. But the attack on the Myers Bill was flogging a dead horse, for it was now evident that agreement was going to settle on the O'Mahoney substitute, and Langer accepted the substitute. ${ }^{156}$

The O'Mahoney Bill (S. I974) had been referred to the Committee on the Judiciary when it was introduced on May 3r. The next morning, O'Mahoney met with members of the Committee on the Judiciary and discussed his bill with them, making some changes in it which he had not had time to incorporate in the text by the time he arose on June I to describe his bill. The clerk of the Senate made a notation of the changes as he described them. It was written in a hurry. It was proffered to the Senate without hearings. The Myers Bill provided for a short moratorium; O'Mahoney proposed moratorium forever. His substitute was a permanent revision of the antitrust laws so as "to declare that delivered prices and freight absorption are not unlawful per se."157 The champion of the antitrust laws thus appeared as a champion of permanent amendment to the antitrust laws of a kind that even the sponsors of S. Res. $24 \mathrm{I}$ and S. 236 had not dared to propose.

There have been various explanations of O'Mahoney's maneuver. One of the most favorable interpretations is the suggestion that O'Mahoney figured that Congress was in a mood to enact a serious renunciation of antitrust policy. In order to avoid a more serious rout, he "preferred a strategic retreat in the form of a compromise with the forces of monopoly." fact that the authors of S. 236 did not think that they could get their bill through, and that the Myers Bill which the O'Mahoney Bill replaced was more moderate than the O'Mahoney Bill, at least to the extent of being temporary and not permanent legislation. A sterner critic suggested that O'Mahoney had "become a convert to a different school of economic thought" from that he expressed as head of the

${ }^{154} 95$ Cong. Rec. 7x68 (May 3r, 1949).

${ }^{155}$ Senator Myers showed himself to be concerned over some of the implications of the Morse exposition of the activities of pressure groups. At the end of the Morse speech, Senator Myers wanted his "friend from Oregon" to understand that no steel companies or any others came to Myers while the bill was being prepared. 95 Cong. Rec. 7169 (May 31, 1949).

${ }^{160}$ Id. at 7190 (June I, I949).

${ }^{107}$ Id. at 7204. The other of the two objectives of the bill was to "preserve the strength of the antitrust laws."

${ }^{168}$ Letter to Congressman Wright Patman from Dr. Fritz Machlup, Johns Hopkins University, July 6 , 1949, Small Business Committee Hearings on S. 1008, at 212. 
Temporary National Economic Committee. ${ }^{159}$ The most candid testimony as to what O'Mahoney had in mind is the testimony of Senator O'Mahoney. On the floor of the Senate, O'Mahoney said, ${ }^{160}$

I should like to say to the Senator (Kefauver) that one of the purposes which I entertained in offering this provision was to make sure that the system which has been used, without criticism, by the sugar beet industry, of selling at delivered prices by absorbing freight, should not now be disturbed.

His faithfulness to his mission as a Senator with important state economic interests to promote is evident in his further statement, ${ }^{161}$

I wanted to be sure that that great western industry was not being unduly affected by the decision.

In the course of testimony he gave to the House Judiciary Committee in support of his bill, Senator O'Mahoney also referred to the development of trona deposits in Wyoming through the Westvaco Company, whose representative he had accompanied to the Capehart hearings. O'Mahoney at that time said that he proposed his bill to clear up the law because he felt "it was essential that nothing be done to prevent the investment of private capital in new industry in the United States." $\mathrm{He}$ had told the Westvaco Company representatives that he thought the law did not compel f.o.b. pricing and that (absent conspiracy) the company could sell its product in the market of any other company at a delivered price and absorb freight in doing so. But no lawyer would advise the company so. O'Mahoney cited the four to four split of the Supreme Court in the Rigid Steel case and indicated that after that case it seemed clear to him "that we were erecting a barrier to the investment of private capital in the development of our natural resources and in the development of trade and commerce."163 Beets and chemicals were clearly in the mind of the sponsor of the substitute for the Myers Bill, whatever other aims might have existed.

The Senate was patently confused, as the record shows. Some, like Senator Tobey of New Hampshire, had come well prepared to fight against S. 1008 in the Myers version, on the ground that it would legalize or tend to legalize basing point systems and make the problem of proof of violation of the statutes more difficult for the Federal Trade Commission, or that lawyers might so argue and thereby produce more eventual confusion than clarification. ${ }^{104}$ Tobey felt that he was vot-

\footnotetext{
150 Testimony of Walter Wooden, Associate General Counsel, Federal Trade Commission, Small Business Committee Hearings on S. 1008, at 68. See Senator O'Mahoney's speech before the Chicago Association of Commerce and Industry, June 22, 1949, as an example of the asserted conversion. 95 Cong. Rec. A4289 (June 28, 1949).

${ }^{100} 95$ Cong. Rec. 7211 (June I, 1949).

1 is1 Ibid.

${ }^{103} H$. R. Hearings on S. 1008 , at 4 .

103 Ibid.

${ }^{104}$ See the long statement inserted in the Congressional Record by Senator Tobey, 95 Cong. Rec. 7211-7231 (June I, I949).
} 
ing for something different in the O'Mahoney substitute for the Myers Bill. ${ }^{105}$ But Senator O'Conor of Maryland, who was in charge of the Myers Bill, felt that there was no substantial difference between the two except that the O'Mahoney proposal would have made permanent what O'Conor and Myers had only dared to hope to make temporary. ${ }^{166}$ Senator Myers thought that there was no difference either. As he said: ${ }^{107}$

When I introduced Senate Bill 1008 , in the nature of a moratorium, in the nature of temporary legislation, I was hopeful that at least we might get that much action. However at that time I did not believe that it would be possible to get permanent legislation through the Senate. However with the assistance and guidance of the Senator from Wyoming, we are able to make permanent what we originally sought to make temporary. I congratulate him for his efforts.

The Senate by a voice vote and with no real debate adopted the O'Mahoney Bill as a substitute for the Myers Bill and then passed it, not as S. 1974, but as S. roo8..$^{108}$

105 "Therefore I wish to go on record as saying that I am opposed to the bill [i.e., the Myers Bill] itself. I shall vote for the O'Mahoney amendment in the nature of a substitute." 95 Cong. Rec. 72xI (June I, I949).

100 "We feel that the amendment as proposed by the Senator from Wyoming accomplishes exactly what was intended to have been accomplished by the Committee on the Judiciary on a temporary basis, but now is accomplished on a permanent basis by the suggestion of the Senator from Wyoming, as amended in the several respects to which explanation has been given. Id. at 7231.

${ }^{107} I d$. at 7232.

${ }^{168}$ As it passed the Senate, S. 1008 in Section I provided: "It shall not be an unfair method of competition or an unfair or deceptive act or practice for a seller, acting independently, to quote or sell at delivered prices or to absorb freight: Provided, That this shall not make lawful any combination, conspiracy, or collusive agreement; or any monopolistic, oppressive, deceptive, or fraudulent practice, carried out by or involving the use of delivered prices or freight absorption." lbid. The Clayton Act as amended was further amended by adding that it "shall not be an unlawful discrimination in price for a seller, acting independently" to quote and sell at delivered prices, identical at different delivery points "or if differences between such prices are not such that their effect upon compctition may be that prohibited by this section." Similarly, it was not to be an unlawful discrimination in price for a seller, acting independently, "to absorb freight to meet the equally low price of a competitor in good faith (except where the effect of such absorption of freight will be to substantially lessen compctition), and this may include the maintenance, above or below the price of such competitor, of a differential in price which such seller customarily maintains." The parenthetical phrase is the Kefauver amendment referred to below, infra, note 171 . Section 2 (b) of the Clayton Act as amended was further amended to read: "Upon proof being made, at any hearing on a complaint under this section, that there has been discrimination in price the effect of which upon competition may be that prohibited by the preceding subsection, or discrimination in services or facilities furnished, the burden of showing justification shall be upon the person charged with a violation of this section, and unless justification shall be affirmatively shown, the Commission is authorized to issue an order terminating the discrimination: Provided further, That a seller may justify a discrimination (other than a discrimination which will substantially lessen competition) by showing that his lower price or the furnishing of services or facilities to any purchaser or purchasers was made in good faith to meet an equally low price of a competitor, or the services or facilities furnished by a competitor." The parenthetical phrase is also a Kefauver amendment. Both amendments were designed to retain the rule of the Seventh Circuit Court of Appeals in Standard Oil Co. v. Federal Trade Comm'n, r73 F. 2d 210 (1949), where the effect of price discrimination on competition was held to overcome the defense of good faith. 95 Cong. Rec. 72xI (June I, 1949). At one place, Senator O'Mahoney told Kefauver that he did not think that his bill (before the Kefauver amendment) would "change the ruling under which the Federal Trade Commission now operates" but he later admitted that the effect of his language would be adverse to the rule in the Standard Oil case (Standard Oil Co. v. Federal Trade Comm'n, I73 F. 2d 210 (C. C. A. 7th 1949)). 95 Cong. Rec. 7206 (June $x$, 1949). The fourth section of S. zoo 8 contained definitions, one of which was: "The term "effect may be' shall mean that there is substantial and probative evidence of the specified effect." 
There had been no hearings on it. Some of the Senators obviously did not understand what was happening. O'Mahoney gave only a very general kind of explanation. In fact, some of the provisions were fashioned by question and answer. It seems not to have been in existence forty-eight hours previously. ${ }^{169}$ It accomplished overnight what Capehart and Johnson stopped trying to accomplish after a long struggle of almost a year. The reputation of the Senator from Wyoming as a champion of the antitrust laws seems to have been accepted as a guarantee of his proposal. $^{170}$ Only Senator Kefauver of Tennessee and Senator Long of Louisiana showed signs of doubt. Kefauver got O'Mahoney to accept an amendment that would have refused legal countenance to freight absorption which "will substantially lessen competition."171 The effect of this amendment was to weaken the defense of good faith, and to restore the rule of the Robinson-Patman Act that discriminatory prices were unlawful (good faith or not) where they could not be justified by cost differentials and tended to lessen competition. After the vote, Senator Long said that he was inclined to feel "that when everyone is as happy about a piece of legislation as Senators appear to be, someone is going to be fooled when he wakes up and sees what is in it."172 A subsequent motion on June 6 to reconsider the bill was defeated, ${ }^{173}$ and on that day the O'Mahoney version of S. I008 was referred to the House Committee on the Judiciary. ${ }^{174}$

\section{VI}

\section{From House to House}

The bill which was given no hearings at all before it was proposed to and passed by the Senate, was given no hearings to speak of in the House. According to one witness, the Judiciary Committee announced a one-day hearing which he heard about "by the grapevine."175 One accomplishment of the one-day hearing was to prune the bill of the amendment that Senator Kefauver had had inserted. Although he accepted the amendment on the floor of the Senate, ${ }^{176}$ Senator O'Mahoney appeared a week later at the House Judiciary Committee hearings to propose that it be taken

This would have reversed the rule of Federal Trade Comm'n v. Morton Salt Co., 334 U. S. 37 (1948), where it was held that a "reasonable possibility" of injury to competition could make a price discrimination unlawful. See also Corn Products Co. v. Federal Trade Comm'n, 324 U. S. 726, 742 (r945).

${ }^{100}$ Congressman Walter said that the bill as it passed the Senate had been drafted by Assistant Attorney General Bergson. 95 Cong. Rec. 9158 (July 6, 1949). At another time Senator Johnson of Colorado said that the Federal Trade Commission was the source of the bill. 95 Cong. Rec. Ir49I (Aug. II, 1949), and that Robert Dawkins was the author. Id. at II 492.

${ }_{170}$ See the comments of Senator Lucas of Illinois and Senator Myers of Pennsylvania to this effect. 95 Cong. Rec. 7232-7233 (June I, 1949).

171 Id. at 7211. 'The verb "will" was to be important. See infra, note 236, and pages 305-308.

${ }^{173} I d$. at 7132 . Note that Senator Long was also in doubt and confusion as to what was taking place. He said that even though he was in favor of the O'Mahoney amendment, on the voice vote, he voted against the bill. He thought that the amendment improved the bill, a remark that is difficult to comprehend.

${ }^{173} 95$ Cong. Rec. 739I-7392 (June 6, 1949).

${ }^{176}$ Id. at 7457 .

${ }^{175}$ Angus McDonald, National Farmers Union, in Small Business Committee Hearings on S. roo8, at 84 .

${ }^{170} 95$ Cong. Rec. 7211 (June I, 1949). 
out. ${ }^{177}$ Herbert Bergson of the Department of Justice also appeared and suggested that the Kefauver amendment be removed. ${ }^{\mathbf{1 7 8}}$ While the foes of monopoly were thus engaged in building up the defenses available to respondents charged with lessening competition, Congressman Walter announced that the Federal Trade Commission had authorized him to state that the Commission was not opposed to the legislation, ${ }^{179}$ although it had been opposed to the lesser regulation first proposed by Senator Myers. It is perhaps a tribute to the leadership of O'Mahoney that he had been able to join the Department of Justice, the Federal Trade Commission, Senators Myers, O'Conor, Capehart, Johnson, and McCarran, and Congressman Walter in a consensus for his bill. Because of the weight of this influence and the speed with which the measure moved through legislative channels without adequate hearings, the critics of the O'Mahoney Bill could fight only a rearguard action. ${ }^{180}$ This they did in brilliant fashion, first in the House and then in the Senate. They were caught unawares when O'Mahoney's substitute passed the Senate, but they fought literally from house to house, and won at the least a temporary stalemate when the Senate failed to act on the conference version of the O'Mahoney Bill at the end of the First Session of the Eighty-first Congress.

The first attack took place in the House Judiciary Committee. Although it was evidently originally intended that the Subcommittee would hold hearings of only one day to hear O'Mahoney and Bergson, opportunity was provided to Congressman Wright Patman to make a statement. ${ }^{181}$ The occasion was the meeting of the full Committee on the Judiciary under the chairmanship of Congressman Celler of New York to decide what action it would take on S. roo8. Before it went into executive session on June I4 to decide to report the bill favorably, Patman and three other Congressmen were heard. He urged the Committee to hold a complete and full hearing because the bill, in his opinion, would "put a loophole in the antitrust laws that a B-36 could fly through."182 There was no other argument he could make since the Subcommittee had already reported to the full Committee, and the discussion of the merits was presumably foreclosed. There had never been, of course, any public discussion anywhere on the merits. Congressman Jennings

${ }^{172} H$. R. Hearings on S. zoo8, at 9. A later discussion showed that the printed version of the Kefauver amendment was not in the form the author intended. It had passed in a form more restrictive of the Federal Trade Commission than he had at first thought. See 95 Cong. Rec. II477 (Aug. Ir, 1949).

${ }_{178} H$. R. Hearings on $S .1008$, at 12.

${ }^{170} \mathrm{Id}$. at 6,28 . In an ambiguous statement, the Commission seemed to imply that the Kefauver amendment needed to be eliminated or modified in order to make good faith meeting of the lowcr prices of a competitor a complete defense to a charge of unlawful discrimination, although it did not make elimination of the Kefauver amendment a condition of approval. See reference to a caucus between Congressman Walter and Commission Staff on June 7,1949 , in the letter of Commissioner Davis to Congressman Walter, dated June 9, 1949, H. R. Hearings on S. 1008, at 60-62.

${ }^{180}$ The Journal of Commerce, in an editorial of June 8, 1949, was suspicious of the approval extended to S. 1008 by the Federal Trade Commission and of Senator O'Mahoney's sponsorship of the permanent legislation. See H. R. Hearings on S. 1008, at 68 .

${ }^{181} H$. $R$. Hearings on S. 1008 , at 17 f.

${ }^{189}$ Ibid. 
of Tennessee tried to get Patman shut of ${ }^{183}$ but without success. ${ }^{184}$ Much of the questioning of Congressman Patman was heckling and argumentative. Congressman Robert J. Corbett of Pennsylvania, representing the Pittsburgh area, said that he supported the bill because "business does ask for an immediate decision on this problem,"185 and a Congressman from Peoria, "where a number of large, bulky industries are operating," agreed with Corbett. ${ }^{186}$ With these statements, which took an hour and a quarter, the Committee went into executive session and decided to report the bill favorably.

The bill was reported to the House, June 2r, $1949 .{ }^{187}$ The Committee report recommended the deletion of the Kefauver amendment ${ }^{188}$ and spoke of clarification when it should have spoken of reversal of the courts. The Cement case, the Rigid Steel Conduit case, and the rule in the Standard Oil Company case were now all involved, since the bill would have given new defenses to those practicing freight absorption, making prices identical with those of competitors, and injuring competition, so long as "good faith" was present. The Kefauver amendment at least would have sustained the rule of the Standard Oil case. The O'Mahoney version would have reversed the rule of the Standard Oil case. As to Rigid Steel, Representative Walter said that the Federal Trade Commission was embarrassed to admit that it had made a mistake in pressing for favorable judgment on Count II in the Rigid Steel case. ${ }^{189}$ The O'Mahoney Bill would probably have inhibited the Commission from proceeding against firms consciously paralleling prices, regardless of the effect on competition, where deliberate conspiracy was absent.

On June 30, I949, the Rules Committee of the House granted an open rule providing for three hours general debate on S. 1008.190 Representatives Celler and Walter of the Committee on the Judiciary urged the granting of the rule, and Patman opposed it unsuccessfully. The best he could do was make a speech warning the members of the House that S. 1008 was on its way. ${ }^{191} \mathrm{He}$ was active in another direction, however. As chairman of the House Select Committee on Small Business, he undertook himself to hold the hearings on S. I008 which he said had been denied to him and to small business groups. ${ }^{192}$ And for five days, witnesses made appearances before the Small Business Committee or sent statements attacking S. 1008. Professional economists, ${ }^{193}$ representatives of small business organiza-

183 Id. at 23 .

184 Id. at 24.

280 Id. at 31 .

180 Id. at 35.

${ }^{287} 95$ Cong. Rec. 8243 (June 21, I949).

${ }^{188}$ H. R. REp. No. 869, to accompany S. 1008, 81st Cong., Ist Sess. I (I949).

${ }^{280} H$. R. Hearings on $S$. 1008 , at 27 .

${ }_{100} 95$ Cong. Rec. D640 (June 30, 1949).

${ }_{101} 95$ Cong. Rec. 8936 ff. (June 30, 1949).

${ }^{102}$ Celler of New York found this maneuver "unseemly" because the Patman Committee was not a legislative committee, had no direct power to recommend legislation, and had no jurisdiction over S. ro08. Jurisdiction was in the Committee on the Judiciary, of which Celler was chairman. 95 Cong. Rec. 9 I64 (July 6, 1949).

${ }^{103}$ Small Business Committee Hearings on $S .1008$, at 135, 212, 215. 
tions, ${ }^{194}$ wholesale and retail distributors, ${ }^{195}$ the National Farmers Union, ${ }^{106}$ the American Trucking Association, Inc., ${ }^{19 T}$ and staff of the Federal Trade Commis$\operatorname{sion}^{198}$ made a record of protest of 300 pages, the theme of which was that S. 1008 would weaken the antitrust laws, cancel recent gains in the clarification of the laws, create more confusion and litigation, make it easier for violators to justify infractions, and harder for the Federal Trade Commission to halt such infractions. Walter Wooden, Associate General Counsel of the Commission, thought that S. 1008 would set back the Commission twenty-four years to the time of the Old Cement case. $^{100}$

Having failed to prevent the granting of a rule to S. I008, Patman then sought to delay the schedule of the Rules Committee in setting the time for the debate on S. 1008, but failed in this also. ${ }^{200}$ In the course of discussing the schedule, however, Patman was able to forewarn the House of the principal objections that his select committee had developed. ${ }^{201}$ He also kept the Appendix of the Congressional Record filled with editorials and extended remarks showing the impact of basing point systems on various geographical areas in the country. ${ }^{202}$ The rule was called up as scheduled, and the House debate on S. roo8 began on July 6, 1949. ${ }^{203}$

The ignorance and confusion of the Congressmen in discussing the measure were depressing. ${ }^{204}$ Brown of Ohio asserted that there had been "rather extensive hearings" on the bill before the Subcommittee and then the full Committee on the Judiciary, ${ }^{205}$ which was not so. Sutton of Tennessee said that he had talked with the person in charge of the Antitrust Division of the Department of Justice by telephone the day before and had been told that the legislation was not necessary at all. ${ }^{206}$ The attitude of the Department of Justice was variously expressed, and Walter of Pennsylvania asserted that Bergson had said that "it was absolutely necessary" that the bill be enacted. ${ }^{207}$ This dispute was settled only when Majority

${ }^{104}$ Id. at 225 .

${ }^{195} \mathrm{Id}$. at 3, 4, 9, $2 \mathrm{I}$.

${ }^{100} \mathrm{Id}$. at 75.

$107 \mathrm{Id}$. at 102.

${ }^{198}$ Id. at 30, I4I, 202.

${ }^{108} 1 d$. at 36 . Cement Mfg'rs Protective Ass'n v. United States, 268 U. S. 588 (1925).

20095 Cong. Rec. 9029 (July 5, 1949). Majority Leader McCormack hinted that Patman's request was tardy and that the bill might have been scheduled to Patman's satisfaction, had he been more prompt in his request.

${ }^{202} \mathrm{Id}$. at $9032 \mathrm{ff}$.

${ }^{203}$ ld. at A445I, A4452, A4477. See also 95 Cong. Rec. A3518, A3542, A3558 (May 31, 1949). Congressman Walter inserted a speech he made before the Peansylvania Bar Association in which the decisions of the Federal Trade Commission on pricing were found to resemble the philosophy of a former Soviet Commissar of Justice. Special reference was made to Count II in the Rigid Steel case. S. I008 was designed to combat the "Krylenko philosophy" represented by the Federal Trade Commission. 95 Cong. Rec. A4454 (July 5, I949).

20395 Cong. Rec. 9157-9x72 (July 6, I949).

204 Congressman Lyle of Texas made an accurate observation when he remarked that "Generally, legislation coming to the floor under a rule is better understood than this particular bill." II. at 9157. ${ }^{205}$ Ibid.

${ }^{200} I d$. at 9158 .

${ }^{20 z}$ The record of the hearings before the House Committee on the Judiciary does not disclose such a statement by Bergson. It does quote him as saying, "Insofar as the Department of Justice is concerned, 
Leader McCormack declared that the bill had the approval of the Commission, the Department of Justice, the Bureau of the Budget, and the White House. ${ }^{208}$ Patman said that O'Mahoney had "agreed to this substitute" (for the Myers moratorium) "only when the Kefauver amendment was added to it."209 The record of course shows that he personally appeared before the House Judiciary Committee to get the Kefauver amendment stricken.

The chief accomplishment of the House was to write in another version of the Kefauver amendment after Patman failed to prevent the debate on the bill scheduled by the Rules Committee. ${ }^{210}$ Willis of Louisiana led the first attack to restore the Kefauver amendment or another version of the amendment, ${ }^{211}$ but this was defeated. ${ }^{22}$ The second (and successful) effort to undo the work of the Committee on the Judiciary in striking out the Kefauver amendment was led by Carroll of Colorado. ${ }^{213}$ The object of the Carroll amendment, as of the Kefauver and Willis amendments, was to deprive respondents under the Robinson-Patman Act of the defense of good faith where differential prices to meet those of a competitor (without differentials of cost) substantially lessened competition. Like the Kefauver and Willis amendments, its effect was to retain the rule of the Standard Oil case as decided by the Seventh Circuit Court of Appeals. ${ }^{214}$ The Carroll amendment was adopted by the Committee of the Whole House ${ }^{215}$ after a wearying debate in which few were on the floor and the speakers complained about the noise. ${ }^{216}$ Since the House passed S. 1008 in a different form from the Senate, the measure was almost certainly headed for a conference committee unless the Senate accepted the House version. ${ }^{217}$ This would have been true also if the Judiciary Committee

we have never urged the necessity or desirability of legislation with respect to the pricing practices to which the present bill is directed." H. R. Hearings on S. 1008, at II.

${ }^{208} 95$ Cong. Rec. 9164 (July 6, 1949). Patman was of the opinion that the Department of Justice was willing to restrict the operations of the Federal Trade Commission out of a sense of rivalry. Id. at 9227. He could not understand why the Federal Trade Commission had changed its position. Ibid. 200 Id. at $9 \times 58$.

${ }^{210}$ The vote on the rule was easily carried, $i d$. at 9167 , and the House proceeded to consider the measure on its merits, with time divided equally between opponents and proponents for three hours. Id. at $9 \times 68$.

31195 Cong. Rec. 9239-9240 (July 7, I949).

310 Id. at 9250 . It is of interest that 143 Congressmen out of the total membership of 435 voted down the Willis amendment by a vote (on division) of $80-63$.

${ }^{213}$ Ibid.

214 95 Cong. Rec. 9170 (July 6, I949).

${ }^{210} 95$ Cong. Rec, 9259 (July 7, 1949). The vote was 117-81. Where the Kefauver amendment had used the words "except where the effect of such absorption of freight will be to substantially lessen competition," the Carroll amendment said "except where such absorption of freight would be such that its effect upon competition may be that prohibited by this section." Where the Kefauver amendment used the words "other than a discrimination which will substantially lessen competition," the Carroll amendment said, "if the discrimination is not such that its effect upon competition may be that prohibited by this section." Compare Carroll amendments with $S$. 1008 as it passed the Senate, supra note I68. As S. I008 passed the House, the phrase "substantial and probative evidence" in the definition of "the effect may be" had been changed to "reasonable possibility," thus restoring the rule of the Morton Salt case. See note 168 stipra.

${ }^{220}$ See remarks of Christopher of Missouri, 95 Cong. Rec. 9256 (July 7, 1949), and White of Idaho, id. at 9258 .

212 The House passed the bill by voice vote after a motion to recommit to the Committee on the Judiciary was defeated. Id. at 9269 . 
version of the measure had been adopted intact by the House, since that version had eliminated the Kefauver amendment.

With the action of the House on the Carroll amendment, a sharp and fairly definite issue was for the first time joined. There was now a line, on one side of which the spokesmen for the Robinson-Patman Act could stand, and on the other, the spokesmen for legislative intervention on behalf of the steel, oil, cement, and building materials industries, all affected by recent decisions. The question was not now the abstract one of basing point systems and required f.o.b. pricing, nor freight absorption as such, nor moratoriums. After the action of the House, Senator Long of Louisiana warned the Senate that he recognized the existence of a drive to end the Robinson-Patman Act, and referred to a statement in the Journal of Commerce which spoke of Celler of New York as the sponsor of such a drive. ${ }^{218}$ A statement attributed to Celler suggested that the conference committee might not have to take either the Kefauver or the Carroll amendments. ${ }^{210}$ Long put the Senate on notice that he regarded the issue as a serious one and was prepared to make a fight on it.

On July 26, the Vice-President laid before the Senate the amendments made by the House to S. 1008, and McCarran of Nevada moved that the Senate disagree with the House and go to conference. ${ }^{20}$ This was quickly agreed to by the Senate, and McCarran, O'Conor, and Wiley were appointed Senate conferees. Long and Kefauver immediately protested the action, charging McCarran with violation of an understanding to give notice to Kefauver when the conference vote would arise, to permit them instead to move to concur in the House amendments. ${ }^{221}$ The McCarran motion to send the bill to conference, sotto voce, almost succeeded in preventing the Senate from debating S. Ioo8 at all. Senate protocol, had McCarran consented, would have nullified the vote to send the bill to conference. He, however, would agree only to a debate on Long's motion to reconsider, which is not a debate on the merits. ${ }^{222}$ The debate was held on August 10, II, and 12, and it failed to persuade the Senate to recall its decision to send S. 1008 to conference. ${ }^{\text {2a3 }}$ Before the matter was sent on its way to the House again with a request to appoint conferees, Senator Lucas of Illinois said that had he known the bill was going to cause so much trouble and take up so much time, it never would have got off the calendar. He had been persuaded to take it off the calendar by Senator Myers of Pennsylvania who had assured him "that it was a moratorium bill, which would probably require a couple of hours." ${ }^{224}$ The weapon that McCarran had against

${ }^{218} 95$ Cong. Rec. 9310 (July 8, 1949).

2197 bid.

${ }^{220} 95$ Cong. Rec. 10387 (July 26, 1949).

221 Id. at $10387-10388$.

${ }^{222}$ See discussion of this point by Senator Morse, 95 Cong. Rec. I1496-11497 (Aug. II, 1949).

228 The motion to reconsider was rejected August 12, 1949. 95 Cong. Rec. ri553-11589 (Aug. 12, 1949).

${ }_{284} 95$ Cong. Rec. II376 (Aug. 10, 1949). Senator Lucas on two occasions tried and failed to get the debate limited by unanimous consent. He succeeded on the third attempt, but only after the supporters of the motion to rcconsider had developed their attack at length. Id. at II400, II47x, II5Io. 
the Long-Kefauver group throughout the three-day debate was the rule of the Senate that a motion to table the motion to reconsider would have the effect immediately of shutting off debate. ${ }^{225}$ This advantage was not pressed, however.

The familiar ground was traversed once again, the chief difference being the new alertness of senators who had had the time and the inclination to inform themselves about matters upon which they had voted unknowingly when the O'Mahoney substitution for the Myers moratorium was made. O'Mahoney expressed again his interest in the development of trona deposits in Wyoming and his desire to make sure that Wyoming concerns would be permitted to absorb freight and quote delivered prices. ${ }^{226}$ He also said that he thought his sponsorship of S. 1008 was consistent with his views when he was head of the TNEC. He said that he had been glad to accept the Kefauver amendment when it was introduced originally and hoped that it, or language like it, would come out of the conference committee intact. ${ }^{22} \mathrm{He}$ did not say that he had gone to the House Judiciary Committee to urge its removal. ${ }^{228}$ Senator Myers said that he had no objection to either the Kefauver or the Carroll amendments but thought that the bill should go to conference because there were such deep cleavages on both sides. ${ }^{229}$

The principal speeches in favor of the motion to reconsider the vote to send the bill to conference were made by Senators Douglas, Long, Kefauver, Hill, and Morse. Senator Douglas, especially, made the most coherent and logical exposition to be made on either side of the controversy. ${ }^{230} \mathrm{He}$ took the bold view that the bill even with the Carroll amendment would legalize basing point systems, and that although the Carroll amendments improved the measure originally introduced, we would still be better off with no bill at all.231 The principal instrument for the suppression of price competition is the basing point system, and this the

225 Id. at 11377.

${ }^{220} I d$. at $\mathrm{I} 1394$.

${ }^{927}$ Id. at $\mathrm{I} 1395-11396$.

${ }^{298}$ At still another place in the debate, on August II, Senator O'Mahoney again said that he had accepted the Kefauver amendments in the Senate because he "believed they were totally in harmony with the purposes of the author of the substitute." 95 Cong. Rec. II489 (Aug. Ir, I949). He failed to state at this time also that he had gone to the House Judiciary Committee to have the amendments stricken.

22095 Cong. Rec. 11398 (Aug. 10, 1949).

930 Senator Capehart was the originator of several short, sharp exchanges with Senator Douglas. The first exchange ended with the following colloquy: Mr. Capehart: "If the Senator wants an argument and a fight I will be very happy to give it to him. The Senator seems to be inviting it." Mr. Douglas: "I fight only in a good cause. If the Senator wants to take me on while $I$ am defending a good cause, I am willing." 95 Cong. Rec. I I 4 or (Aug. I0, 1949).

231 Id. at II 400. He mentioned trade-marked consumer goods like chocolate bars and other candies, chewing gums, cigars, soap, cosmetics, drugs, shirts, soft drinks and the like which sell all over the country at the same price (indicating freight absorption) and are protected by trade-mark. As to these the Federal Trade Commission had not proceeded against the uniform prices of trade-marked products and there was no prospect that it would. These are different from the standardized commodities in which there is little difference of quality, and price competition is the only kind that counts. Among the latter are steel, cement, lead, steel pipe and conduits, corn syrup, beet sugar, some forms of lumber, and brass. He said that the makers of the latter had been fighting behind the skirts of the first to legitimatize their own monopolistic practices. 
O'Mahoney Bill, even with the House amendment, would sanctify. ${ }^{232}$ The alleged confusion following the Rigid Steel case existed only in the minds of those sponsoring the O'Mahoney measure and not in the minds of the courts or the Federal Trade Commission. The fact that the Court split four to four in the Rigid Steel case need not have made legislation any more necessary than the four to four split in the Oregon minimum wage case in $1917 .{ }^{233}$ Any further amplifications or refinements of statements about the law and its application should be undertaken by the administrative and the judicial processes. The present laws are adequate to deal with the situation and new legislation is unnecessary. ${ }^{234}$

Kefauver of Tennessee repeated many of the points that had been mentioned and developed some further. ${ }^{235}$ The O'Mahoney Bill he thought was unnecessary. It added to and did not lessen confusion. But if it should be enacted, it should contain the Carroll amendments. The junior Senator from Tennessee in fact thought that the Carroll amendments were broader and provided more protection to small business $^{236}$ than his own. Kefauver reviewed the cases which the O'Mahoney Bill would affect (indeed, set aside) including the familiar five: Corn Product, Staley, Cement, Rigid Steel, and Standard Oil-in short all of the cases in which the profile of the law was becoming more and not less clear and certain. ${ }^{237}$ Like Douglas, Kefauver hoped that the bill would be defeated. The minimum condition of acceptance, he felt, should be the adoption of the Carroll amendments. ${ }^{238}$ There was a strong implication that the Senators sponsoring the bill did not know what they were doing when Kefauver said that the purpose of the measure was to emasculate the antitrust laws, a purpose that the sponsoring Senators did not embrace, but which was the design of "the great lobby that is behind the bill.".230

\footnotetext{
${ }^{232}$ Douglas cited a letter written to him at his request by the Chairman of the Department of Mathematics at Haverford in which it was estimated that the probability of eight identical bids in 102 counties was one in eight followed by 214 zeros. The Illinois Department of Highways in 1947 had received bids from eight cement companies which were identical within each of the I02 counties in the state. Id. at $\mathrm{x} 1403$.

${ }^{233}$ Stettler v. OHara, 243 U. S. 629 (I917).

234 95 Cong. Rec. II405 (Aug. 10, 1949). The Kefauver and Carroll amendments would only have "limited the bare-faced use of the basing point system," not made it obviously unlawful. Id. at 11408. Capehart said that Douglas was confusing the right of individual sellers acting independently to absorb freight with the basing point system. There is perhaps less confusion than overlapping between the two. Not all freight absorption is basing point in structure, but typical basing point systems involve freight absorption. A bill making all non-conspiratorial freight absorption lawful regardless of effect on competition could be understood to legalize basing point systems, as Douglas asserted. 95 Cong. Rec. II 4 I2 (Aug. Ir, I949).

235 Kefauver's principal presentation is to be found in 95 Cong. Rec. 1x475 ff. (Aug. 11, 1949).

${ }^{338} \mathrm{ld}$. at 11477 . When he first proposed his amendment Kefauver proposed to insert the words "except where the effect of such absorption of freight will be to substantially lessen competition." He then thought that the word "will" was incorrect since the word "may" customarily appears in antitrust legislation, and substituted the word "may" for the word "will" in the printed copy of his bill. It was adopted by the Senate with the word "will," however, raising a matter of some concern to the conference committee when it looked for a version of the Kefauver-Carroll amendments that would be satisfactory to both the House and the Senate.

${ }^{237} I d$. at $\mathrm{I} I 476$.

${ }^{238}$ Id. at II 485 .

${ }^{230}$ Ibid.
} 
Hill of Alabama and Morse of Oregon made the last two speeches of importance in favor of the motion to reconsider. Hill drew freely upon the views of witnesses before the Patman Small Business Committee, ${ }^{240}$ and the reported views of the Federal Trade Commission, ${ }^{241}$ the Department of Justice, ${ }^{242}$ and the press. ${ }^{243}$ Morse of Oregon, although feeling that the bill would eventually pass into law, ${ }^{244}$ nevertheless conducted a vigorous attack upon it. He deplored what seemed to him to be a breach of the usual senatorial practice when sentiment exists to reconsider a vote by which bills are sent to conference. The customary practice he had found was to permit reconsideration by unanimous consent, without debating the motion. ${ }^{245}$ This courtesy had been withheld by the chairman of the Senate Judiciary Committee, who had originally called for a vote on sending the bill to conference when Kefauver, with whom he had had an agreement to give prior notice, was not in his seat. ${ }^{246}$ Morse wanted the record to show that the proponents of the bill wanted to take refuge in the protection of a technicality in the rule. ${ }^{247}$

Morse preferred the Carroll amendment to the Kefauver amendment because the latter contained the inadvertent word "will" and he applauded Kefauver's forthrightness in accepting the Carroll amendment in place of his own. ${ }^{248}$ He made an exposition of the actual operation of basing point systems, ${ }^{249}$ thereby carrying forward the excellent lecture given to the Senate by Douglas and others on economics. He twitted O'Mahoney with a news release issued by the Senator from Wyoming and dated July II, $\mathrm{r} 948$, in which the basing point system was condemned, the reader was warned that the steel industry would try to lay the basis for a demand that Congress change the antitrust law, and the case was made for a good faith abandonment of the basing point system in favor of f.o.b. pricing. ${ }^{250}$ He thought that the news release left some in doubt as to how the Senator from Wyoming could justify his position on $\mathrm{S}$. 1008 .

On the last day of the three-day debate on the motion to reconsider, the time was divided equally (under a unanimous consent agreement) beween the supporters and opponents of the motion. Wherry of Nebraska led off against the motion to reconsider by asserting that the bill (S. 1008) had been used as a medium for

${ }^{200} \mathrm{Id}$. at II $490, \mathrm{II} 495$.

${ }^{211} \mathrm{Id}$. at II $49 \mathrm{I}$.

${ }^{243}$ Ibid.

${ }^{313} I d$. at 11495 .

${ }^{214}$ In a colloquy with Senator Douglas, Senator Morse said: "But I am sure the Senator from Illinois will agree with me that the probabilities are that Senate Bill I008 will be finally passed by the Senate." Id. at 11498 . And again, "But I recognize that a bill is going to be passed, and therefore I am going to do the very best I can to patch it up." Id. at II503.

345 Id. at II496.

$240 I d$. at $x \times 497$.

${ }^{247}$ Long of Louisiana was also absent, being "on my way to the Senate Chamber at the time the motion was made." 95 Cong. Rec. 10387 (July 26, 1949). The agreement was made between McCarran and Kefauver. Russell of Georgia had also asked McCarran to be notified. Long spoke of the "low tone of voice" in which McCarran had put the motion to send the bill to conference. Id. at I0388.

${ }^{348} 95$ Cong. Rec. Ir 498 (Aug. II, 1949).

260 Id. at II $498-x I 508$.

${ }^{250}$ Id. at II $508-x I 509$. 
airing wholesale violations of the antitrust laws. He thought that $S$. 1008 was designed to restore the competitive conditions "which were revolutionized by the Supreme Court opinion in the Cement case."251 The issue was a simple one, and he proceeded to explain it in terms of horse trading on the farm. Douglas made a summary of his previous speech. ${ }^{252}$ O'Conor of Maryland concentrated upon the Carroll amendments which he thought meant to "amend the Robinson-Patman Act except in any respect in which it is in force."253 Among the authorities invoked in favor of S. roo8 was John D. Clark of the Council of Economic Advisers, described by Johnson of Colorado as a great liberal who, although his father left him a fortune, "did not become a playboy at all."254

The suggestion made the day before by Morse, that Senator O'Mahoney was professing a view inconsistent with that he held on July Ix, I948, was further developed by Long. ${ }^{255}$ O'Mahoney maintained his position that S. I008 contained nothing which affected the basing point system or the multiple basing point system. ${ }^{250}$ $\mathrm{He}$ argued that if S. 1008 were defeated, steel could go back to f.o.b. mill prices and then prevent any other state from developing a steel industry. ${ }^{257}$ It was put to him that he had once said that it was best for the steel companies to go on an f.o.b. pricing basis. O'Mahoney's answer was that the TNEC report had indicated that a change in f.o.b. pricing must allow industry time for adjustment. He saw around him now opportunities for new competitive enterprises to enter industry, and believed that they could not do it without being permitted to absorb freight. ${ }^{258}$

Sparkman of Alabama reviewed the history of the pressure which had been organized to produce changes in the antitrust laws by Congress. ${ }^{250} \mathrm{He}$ paid special attention to the effect of the abolition of the basing point system on the sugar beet industry of Colorado, Wyoming, and other Mountain States and concluded that the result would not be harmful to that industry in those states. ${ }^{200}$ This seems to have been an appeal to the chief proponents of the legislation from important sugar beet states, Johnson of Colorado and O'Mahoney of Wyoming. Pepper of Florida developed the case against the basing point system with special reference to Florida. ${ }^{201}$ With some further remarks by Long and Kefauver, the struggle to

25195 Cong. Rec. $x 1554$ (Aug. 12, 1949).

${ }^{262}$ Id. at $11557-11559$.

${ }^{253} I d$. at 11563 .

${ }^{254}$ Id. at II 492. See testimony of Clark cited by O'Conor, $i d$. at I 1563 . Long of Louisiana suggested that Clark was one of the "great Standard Oil executives," who had been "one of the foremost advocates of the legalization of the basing-point system itself" and that if the bill met with Mr. Clark's approval that fact might "indicate that the bill might actually legalize the basing-point system." Id. at I I 492.

205 Id. at 11572.

$250 \mathrm{Id}$. at $\mathrm{I} 1573$.

${ }^{257}$ Ibid.

${ }^{208} 7$ bid.

${ }^{259} \mathrm{He}$ also utilized the material reported by James W. Daniel, Washington correspondent of the Rocky Mountain News, Dec. I7 and 22, $\times 948$, describing the activities of an organization which set out to produce a "grass roots demand" for change in the law. Id. at 11575 .

${ }^{200} \mathrm{Id}$. at II I575-1 1578.

${ }^{201}$ Id. at I1579-11582. 
get the Senate to reconsider the motion to send the bill to conference ended. It was a struggle that had been waged in the main by Senators from southern and midwestern states against Senators from the steel and beet sugar states.

Before the vote was taken on the motion to reconsider, McCarran undertook to defend O'Mahoney, as Johnson had previously done. ${ }^{262}$ The McCarran statement was notable chiefly for the suggestion that the O'Mahoney Bill was more antimonopolistic than "any bill which was likely to come out of the Committee on the Judiciary after the year of study which was contemplated during the period of moratorium" which the Myers Bill would have provided. ${ }^{263}$ The motion to reconsider the vote to send $\mathrm{S}$. 1008 to conference was lost $28-49,{ }^{264}$ and McCarran was stopped by Langer of North Dakota in a maneuver to have O'Mahoney and Jenner of Indiana added to the conference committee. ${ }^{265}$

\section{VII}

\section{The Conference Report}

The final passage at arms in the First Session of the Eighty-first Congress took place over the conference committee report which was submitted in the closing days of the session. ${ }^{266}$ As reported by the conference committee, the compromise bill was unacceptable to Celler, chairman of the House Judiciary Committee, and Willis of Louisiana. ${ }^{207}$ It was acceptable to the three Republican conferees and one Democrat, Representative Walter of Pennsylvania, who was on the high seas but had cabled his proxy, not to a member of his party, but to a member of the minority party. ${ }^{208}$

S. 1008, as finally proposed in the conference report, amended the Federal Trade Commission Act to provide that it should not be regarded as an unfair trade practice for sellers acting independently to absorb freight and quote delivered prices. ${ }^{269}$ Language withheld the benefits of the Act from any combination, conspiracy, or collusive agreement, and from any monopolistic, oppressive, deceptive, or fraudulent practice carried out by the use of freight absorption or delivered prices. This

202 Johnson had said, "The chemical industries of the West wanted to go ahead without further delay. They had to have matters clarified so they could develop the industries they had in mind. Industries wanted to get under way in Wyoming. They were demanding that the matter be settled. They persuaded the Senator [i.e., O'Mahoney] they needed action at once and the present bill is the result. Id. at 11573 .

${ }^{203}$ Id. at 11583 .

$204 I d$. at 11588 .

${ }^{205}$ McCarran asked for unanimous consent to augment the number of Senate conferees and to add Jenner and O'Mahoney, but Langer objected and unanimous consent was therefore not secured. Id. at II 589 .

${ }_{200}$ After the Senate action sending the measure to conference, the House insisted on its amendments, agreed to the conference (95 Cong. Rec. II8II (Aug. 16, r949)) and appointed conferees, August I6, 1949. The conference report, H. Rep. No. $\mathrm{r}_{422}$, was submitted to the House on October r4, I949, and debated. 95 Cong. Rec. 14786 (Oct. 14, 1949).

20795 Cong. Rec. 14786 (Oct. I4, 1949).

${ }^{209}$ Michener of Michigan. Walter's views about the legislation were closer to those of Michener than to either of the other two conferees of his own party. See Michener's statement, id. at r4794.

${ }^{200} \mathrm{Id}$. at I4794-1 4795 . 
language had been included in both House and Senate versions of S. roo8. The Robinson-Patman Act was amended to make it lawful for sellers independently to absorb freight or quote delivered prices unless the effect of these practices "upon competition will be to substantially lessen competition." This was the version of the Kefauver amendment that Kefauver had repudiated. Even where the forbidden effect was shown, however, the conference report provided that good faith meeting of the lower prices of a competitor should be a complete defense to a charge of unlawful discrimination, regardless of its effect upon competition. It was therefore possible for the Federal Trade Commission to prove a prohibited discrimination to which good faith would be a complete defense.

The press reported (as the conference report indicated) that $S$. roo8 would overrule the Seventh Circuit Court decision in the Standard Oil case, where a prohibited effect upon competition vitiated the defense of good faith in a charge of unlawful price discrimination. ${ }^{270}$ Moreover, language of the proposed bill required the Commission to demonstrate illegal effects of price discrimination with "reliable, probative and substantial evidence." This threw out the rule of the Morton Salt case, where the Commission had been required to prove only a "reasonable possibility" that the effect of a price discrimination would injure competition unlawfully. The general exemption extended to non-conspiratorial freight absorption would have nullified the holding on Count II in the Rigid Steel Conduit case, and would have weakened the theoretical basis of the Cement case, and the Glucose cases which preceded it.

Carroll of Colorado supported Celler's objection to the conference report and explained the circumstances under which the word "will" had come into the Kefauver amendment instead of "may." He proposed that the report be recommitted or that no legislation on the subject at all should be sought. ${ }^{271}$ Others felt as Carroll did. ${ }^{272}$ Strong statements in support of the conference report were made by Halleck of Indiana ${ }^{273}$ and Michener of Michigan. ${ }^{274}$ The proceedings were short, and after a motion to recommit was lost, ${ }^{275}$ the conference report was adopted by the House by a vote of 200-104. ${ }^{276}$

With the submission of the conference report to the Senate, ${ }^{277}$ the opponents of S. 1008 had picked up another ally-time. ${ }^{278}$ The Senate was in the last days of the First Session of the Eighty-first Congress, and the Congressmen wanted to expedite their business in order to get home. O'Conor was reported to be confident

${ }^{270}$ Wall Street Journal, Oct. I3, I949, p. 8, col. 2.

27195 Cong. Rec. 14788 (Oct. 14, I949).

${ }^{272}$ For example, Boggs of Louisiana, $i d$. at ${ }_{44789}$.

${ }^{273} \mathrm{Id}$. at $\mathrm{I} 4789-\mathrm{x} 4790$.

${ }^{374} I d$. at $14794-14796$.

${ }^{275} I d$. at 14797 . The vote was $138-178$, with 116 not voting.

${ }^{270} I d$. at $14797-14798$. There were 128 not voting.

${ }^{277} 95$ Cong. Rec. 14983 (Oct. 15, 1949).

${ }^{278}$ See 95 Cong. Rec. I5054-15055 (Oct. 17, 1949), where Lucas of Illinois arranged the schedule of the Senate, including the conference report debate. 
that he had enough votes to push the bill through. ${ }^{2 i 9}$ The-pressure was so great that the sponsors of the conference report actually managed to slip it through the Senate in a Saturday night session with what Douglas described as "supersonic speed."280 The action was recalled by the timely attentiveness of Douglas and Long. The Senator from Illinois said that he and Long were standing close to the Chair, but even then could not hear the question which was stated, "and we were startled by the almost instantaneous announcement that the report had been agreed to." This tactic was reminiscent of the manner in which the motion to send the bill to conference had been maneuvered. If Douglas and Long had not been watching for the Saturday night motion, the Senate would have enacted a fundamental reform of the antitrust laws that had never had hearings in either the House or the Senate, which few legislators understood, and which had been put on the books by inadvertence.

The last debate on S. roo8 began when Douglas objected to the conference report in its entirety. ${ }^{281} \mathrm{He}$ expressed the opinion that S. 1008 legalized the basing point system, the postage stamp and zone systems of pricing, and would produce a reversal of the entire policy of the government in the pricing field. ${ }^{282}$ In addition, he felt that the bill really repealed the Robinson-Patman Act. ${ }^{283}$ Hill of Alabama contributed a recollection of William Jennings Bryan who once in a debate against a tariff bill referred to the banyan tree which entices the unwary native to seek its fruit only to be crushed by the powerful limbs of the tree. ${ }^{284}$ Capehart wanted to talk about the Miller-Tydings Act which Douglas suggested was as relevant to S. 1008 as canasta. ${ }^{285}$ As he had warned in an early phase of his speech, Douglas at its conclusion moved that further consideration of the conference report on S. 1008 be postponed until January $20,1950^{286}$ O'Conor immediately moved to table the motion and on the yeas and nays, the motion was lost, 29-29, the Chair indicating that its vote would be in the negative. ${ }^{287}$

The denouement was supplied by O'Mahoney who turned against the bill he had sponsored, and gave his support to Douglas. He expressed his pleasure that the Douglas motion was not laid upon the table, ${ }^{288}$ and he urged that it be adopted.

${ }^{270}$ The Journal of Commerce, Oct. 18, 1949, p. 2, cols. 6-8. Senator Long told reporters that Douglas would not filibuster, but that he had no objection to doing so. See also Journal of Commerce, Oct. 19, I949, p. I, col. 8, where mention is made of a sizable stack of books brought to the Senate by Long.

${ }^{280} 95$ Cong. Rec. I5II5 (Oct. I7, I949).

${ }^{38 x}$ Douglas got unanimous consent to hold the floor on October $I 7$ and to permit him to resume the debate the next morning, October 18 . Id. at $151 \times 8$.

${ }_{282}^{2} I d$. at $15165-15166$.

$283 \mathrm{Id}$. at $1516 \mathrm{y}$.

294 Id. at $15 \mathrm{I} 68$. Douglas thought that this illustration was more graphic than the spider and $f y$ analogy.

${ }^{285} 95$ Cong. Rec. 15168 (Oct. 18, 1949).

280 Douglas' first motion was to recommit the report to the conference committee with the request that it report on January 20, 1950. This was ruled out of order since the House had already acted. Id. at 15173 .

${ }^{287} I d$, at 15174 .

${ }^{288}$ Ibid. 
His principal point was that the conference committee version of S. 1008 permitted the Federal Trade Commission to proceed against prohibited forms of freight absorption only where the effect of the absorption will be to lessen competition substantially, not where there might be a reasonable probability of this result. ${ }^{280}$ The committee had retained the original or inadvertent version of the Kefauver amendment; O'Mahoney thought that the Carroll version was preferable. O'Mahoney warned that if consideration were not postponed, he would have to vote against the bill that he had introduced. ${ }^{290}$ The conference bill not only did not clear away misunderstandings, but created fresh ones. O'Mahoney said that he had always understood independent freight absorption to be legal and was glad to have the recent opinion of the Fourth Circuit Court of Appeals in the case of Bond Crown and Cork Company v. Federal Trade Commission confirm this belief. ${ }^{291} \mathrm{He}$ concluded by explaining why he had got into the controversy in the first place-Wyoming beets and chemicals ${ }^{202}$-but now felt that the conference report version of his bill would work to the disadvantage of these industries by "locking up the natural resources of the West in the hands of the monopolists." This statement (perhaps it might be called "recantation") was documented by a letter from O'Mahoney to Mr. Robert D. Pike, in which the latter was assured that the courts, the Commission, and the Department of Justice would continue to support the legality of independent freight absorption. ${ }^{203}$

With the conclusion of O'Mahoney's speech, the opposition to Douglas' motion collapsed. The Senate quickly agreed by voice vote to postpone consideration of the conference report to January $20,1950 .{ }^{294}$

\section{VIII}

\section{Sumarary and Conclusion}

The drive to amend the antitrust laws and overrule major decisions of the Federal courts was begun in the summer of 1948 when steel customers, and others, stimulated by the new pricing policy of the steel industry, appeared on the stage of the Capehart Committee and asked that Congress "clarify" the law on pricing. The trouble was not really that the law was unclear but that it was becoming more clear as the Federal Trade Commission and the courts applied the Federal Trade Commission and Clayton Acts (as amended) to new situations. The principal effect of the two measures to enact permanent amendment of these statutesS. 236 and O'Mahoney's S. 1008-would have been to set aside the new decisions. A trend was to be stopped and perhaps reversed, not made more viable in the directions freshly opened.

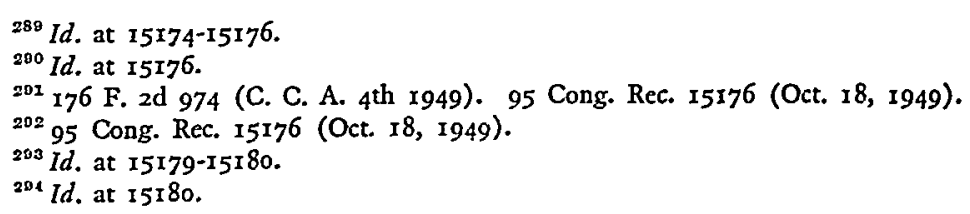


After the somewhat elaborate propaganda prepared by the Capehart hearings for a Congress that the voters did not elect, the effort to write a permanent statutory amendment of the antitrust laws proceeded briefly, but was soon abandoned because of the complexity of the problem and the desire of the proponents of change for quick results. The Myers moratorium was to serve this desire. At the critical point, however, the proponents of legislative intervention against the Commission and the courts found themselves being led, to their joyful surprise, by Senator O'Mahoney, who seems to have been influential in bringing along the Commission and the Department of Justice also. If Kefauver had not amended S. 1008, however inadvertently, as it whisked through the Senate, one of the fastest breaking squeeze plays in recent legislative history would have reversed developments in the law of pricing that had taken years to mature. The Kefauver amendment slowed up proceedings in the House, made a conference necessary, and thereby gave time for an opposition to crystallize and organize. Even with this small gain, two strategems threatened to prevent the new opposition from placing its weight against the insistent thrust to legislate. These were the maneuvers that almost sent S. roo8 to conference on tiptoe, and then almost whirled the conference report through the Senate with "supersonic speed."

Few Congressmen seemed to know quite what they were doing, and on S. I008, at least, there was almost no way for them to find out, since the O'Mahoney Bill was given no hearings in the Senate and no public hearings in the House Judiciary Committee. The only public hearings it received were held by a committee that had no jurisdiction over the measure. The Capehart hearings were useless as a basis for legislation. The residuum which the Capehart hearings leave is that the witnesses, understandably, would feel uncomfortable in the dream world of required f.o.b. pricing that was imagined for them. The hearings on S. 236 were perfunctory at best, and full investigation of alternatives was missing.

The Federal Trade Commission looked no more sure of itself at points than some of the Congressmen. Under pressure, the Commission seems to have abandoned at least one position that it assumed before the courts, and permitted itself to be reported as not in objection to the O'Mahoney Bill, although it had declined to support either S. 236 or the Myers moratorium. Moreover, direct statements were made in Congress to the effect that the Commission staff was responsible for language in the O'Mahoney Bill. Without a full knowledge of all of the considerations that seemed to be pressing and important, it is impossible to judge the necessity of the Commission's choice. The student of antitrust policies may be permitted the hope, however, that the Commission will not lose sight of the trust given it by the statutes to carry forward, not backward, the enforcement of the laws governing competition.

It need not be supposed that those who supported the O'Mahoney Bill were willful wreckers of the antitrust laws, for the choices were not simple and clear-cut. Few argued that required f.o.b. pricing was desirable. Most accepted the view that 
independent freight absorption made in good faith with no adverse effect upon competition was desirable. But neither Johnson, Myers, nor O'Mahoney succeeded in producing a bill to protect this kind of freight absorption without at the same time lending countenance to practices that would be restrictive of competition, be hard to detect, and be harder to prove. It is not difficult to understand that the harassed Congressman, importuned by restless constituents, would prefer to risk abuse of the law if he could protect the concerns of the innocent in intention. Indeed, O'Mahoney himself seems to have made somewhat this kind of choice. The alternatives, however, become a little clearer when it is established that the fears are unfounded. One does not then have to assume the risk. This is the view with which O'Mahoney started. It is the one with which he finished.

A reasonable case can be made for the proposition that the entire antitrust policy of the United States should be reviewed candidly, re-formulated in the light of sixty years' experience, and fitted to suit the requirements both of large scale industry and the public in the middle of the twentieth century. It may be that the complications swamp the benefits of legislation in the pricing field that is too detailed and specific. Free enterprise is a valuable concept which certainly should not be impaired by the very laws enacted to fulfill its promise. But the formulation of new policy requires at the least comprehension of the issues, full hearing for all relevant views, and an earnest effort in good faith to reach a new balance of interests. The movement to change the law on pricing in the First Session of the Eighty-first Congress fulfilled none of these conditions. 